\title{
VARIA
}

TOMASZ WujeWsKI

\section{KOLOS RODYJSKI: GDZIE STAŁ I JAK BYŁ WYKONANY}

$\mathrm{Na}$ temat Kolosa Rodyjskiego napisano już tak wiele, że wydawałoby się, że napisano wszystko. A jednak to słynne dzieło sztuki starożytnej, a właściwie jego legenda, nadal jest przedmiotem kontrowersji i coraz to nowych propozycji ich rozwiązania. Bezpośrednim powodem podjęcia przeze mnie tutaj tematu są niektóre tezy niedawno opublikowanej książki Ursuli Vedder ${ }^{1}$. Nie zostały one zbyt przychylnie przyjęte przez środowisko archeologów niemieckich, a w szczególności ta z nich, według której Kolos stał na akropoli miasta Rodos. Ponieważ od dawna jestem podobnego zdania jak niemiecka autorka, poniżej przedstawiona będzie skromna próba rozszerzenia jej argumentacji. Nie przedstawiła ona bowiem wystarczająco przekonującego dowodzenia i pominęła pewne aspekty, w świetle których ta z gruntu słuszna myśl wydałaby się bardziej atrakcyina. Nie znaczy to, że można zgodzić się ze wszystkimi innymi tezami autorki, w szczególności z jej rekonstrukcją techniki wykonania Kolosa, na co zwrócimy uwagę poniżej.

Tzw. Kolos Rodyjski umieszczano na wielu listach Siedmiu Cudów starożytnego świata². Był to wykonany z brązu posąg Heliosa, wysokości

${ }^{1}$ U. Vedder, Der Koloss von Rhodos. Archäologie, Herstellung und Rezeptionsgeschichte eines antiken Weltwunders, Mainz 2015. Książka jest podsumowaniem kilkunastoletniego zajmowania się problemem: w 1999 opublikowała: eadem, Der Koloss von Rhodos - Neue Perspektiven über das Jahr 2000 hinaus?, w: Proceedings of the XVth International Congress of Classical Archaeology, Amsterdam July 12-17, 1998, red. R.F. Docter, E.M. Moormann, Amsterdam 1999 (Allard Pierson Series 12), s. 335-337.

${ }^{2}$ Literatura na temat Siedmiu Cudów, zarówno naukowa, jak i popularna, jest tak obszerna, że niemożliwe i niecelowe byłoby jej przedstawianie w tym miejscu. Chcę jednak przypomnieć zasłużonego polskiego badacza: R. Gostkowski, Siedm cudów świata, „Kwartalnik Klasyczny" II, 1928, 4, s. 391-440. Z nowszych opracowań można tu wspomnieć o publikacji cieszącej się dobrym wzięciem: K. Brodersen, Die Sieben Weltwunder. Legendäre Kunst- und Bauwerke der Antike, München 1996. 
ok. 70 łokci, co według różnych przeliczeń odpowiada 30-35 metrom. Wcześniej, o ile wiemy, metalowych posągów tej wielkości nie było, aczkolwiek kamienne rzeźby monumentalne dobrze były znane z Egiptu, a i w Grecji archaicznej wykuwano niekiedy figury kilkumetrowej wysokości. W czasach klasycznych zaś były to ponaddziesięciometrowej wysokości chryzelefantynowe rzeźby Ateny Partenos i Zeusa Olimpijskiego. Zatem być może nie sama wielkość ani prawdopodobnie nie nadzwyczajne walory estetyczne były przyczyną sławy Kolosa, lecz osiągnięcie techniczne, jakim było pomyślne jego zrealizowanie, po raz pierwszy w historii cywilizacji.

Historia tej rzeźby wiąże się z oblężeniem miasta Rodos przez Demetriusza Poliorketesa w latach 305-304 przed Chr. Ponieważ nie udało mu się miasta zdobyć, odstąpił spod jego murów, pozostawiając urządzenia oblężnicze. Według niektórych przekazów starożytnych metal pozyskany z tych machin, w szczególności z największej z nich (nazywanej helepolis ${ }^{3}$ ), został wtórnie użyty do wykonania Kolosa. Prace trwały 12 lat, dedykacja prawdopodobnie miała miejsce w roku 283 przed Chr. Po 66 latach dzieło zostało zniszczone w wyniku trzęsienia ziemi, które oblicza się na rok 225-224 przed Chr. ${ }^{4}$ Odtąd destrukt posągu leżał podobno przez wiele wieków ani nie naprawiony, ani nie usunięty. Artystą był Chares z Lindos.

Nie ma wiarygodnych źródeł ikonograficznych co do wyglądu Kolosa ${ }^{5}$. Źródeł pisanych zaś jest stosunkowo wiele (ponad 506), aczkolwiek w większości ograniczają się one do wspomnienia dzieła jako jednego z siedmiu cudów świata. Tekst Filona z Bizancjum, pozornie bardzo szczegółowy i podający technikę wykonania dzieła, jest bałamutny i napisany - jak większość badaczy dzisiaj przyznaje - dopiero w czasach wczesnobizantyjskich ${ }^{7}$. Przypomnijmy pokrótce mogące mieć większe znaczenie informacje z niektórych źródeł.

${ }^{3}$ Jej opis u Diodora, XX, 91.

${ }^{4}$ Lub 227 przed Chr., zob. Vedder, Der Koloss..., s. 20.

${ }^{5}$ Niektórzy uważają, że przyczyną braku źródeł ikonograficznych jest krótki okres egzystowania posągu w formie nienaruszonej, albo niewykształcenie się specyficznej ikonografii Heliosa w ogóle.

${ }^{6}$ H. van Gelder, Geschichte der alten Rhodier, Haag 1900, s. 385.

7 Rzeczywisty Filon z Bizancjum żył w III lub II wieku przed Chr. i był autorem dzieł o mechanice, technikach oblężniczych i obronnych, częściowo zachowanych. Źródło, o którym tu mówimy, to „O siedmiu cudach świata” (peri ton hepta theamaton), napisane pod imieniem Filona zapewne w V wieku (często autor ten jest nazywany Pseudo-Filonem). 
Niewątpliwie najciekawsze odnośne teksty znajdziemy u Pliniusza i u Strabona. Pliniusz ${ }^{8}$ potwierdza, że autorem Kolosa Rodyjskiego był Chares z Lindos, uczeń Lizypa, że posąg mierzył 70 łokci, że po 66 latach ${ }^{9}$ zniszczyło go trzęsienie ziemi. W czasie teraźniejszym pisze, że nawet jego szczątki budzą zdumienie, niestety nie wiadomo, z jakiego powodu. Raczej chyba pod względem ogromu niż artyzmu, albowiem w następnej kolejności czytamy, że kciuk posągu mało kto może objąć, a palce są większe od wielu posągów (chyba ma na myśli posągi naturalnej wielkości ${ }^{10}$ ). Następne zdanie warto zacytować w całości, okaże się to bowiem przydatne dla naszych późniejszych rozważań: vasti specus hiant defractis membris; spectantur intus magnae molis saxa, quorum pondere stabiliverat eum constituens ${ }^{11}$. Potwierdza, że prace trwały 12 lat, kosztowały 300 talentów. Dalej informuje o Demetriuszu i pozostawionym przez niego sprzęcie oblężniczym.

Strabon przytacza cytat z jakiegoś utworu jambicznego potwierdzający autorstwo Charesa z Lindos, 70 łokci wysokości Kolosa i następnie dodaje: „obecnie leży on powalony wskutek trzęsienia ziemi, przełamany w kolanach. Ze względu na pewną wyrocznię nie został podniesiony" ${ }^{\prime 2}$. Zwrot periklastheis apo ton gonaton można tłumaczyć jako „przełamany w kolanach", ale też jako „zgięty w/od kolan” ${ }^{13}$.

8 Pliniusz, NH, XXXIV, 41.

9 W tekście jest co prawda „post LVI annum terrae motu prostratum”, ale uważa się tę liczbę za pomyłkę kopisty i poprawia na 66 lat.

${ }^{10}$ Jeśli owe 70 łokci wysokości całego posągu przeliczymy na ok. $32 \mathrm{~m}$, to znaczy, że Kolos był większy ok. 19 razy od wzrostu naturalnego, który przyjmujemy tu na $170 \mathrm{~cm}$. Zakładając przy tym, że miał prawidłowe proporcje, to jego palec środkowy musiałby mierzyć ok. $170 \mathrm{~cm}$ lub nieco więcej. Z tego wynikałby wniosek, że należy rekonstruować wysokość Kolosa raczej powyżej $32 \mathrm{~m}$. Przy $35 \mathrm{~m}$ wysokości palec miałby ok. $185 \mathrm{~cm}$ długości i byłoby to rzeczywiście więcej „niż niejeden cały posąg” naturalnej wielkości, zakładając, że przeciętny wzrost mężczyzny w czasach rzymskich oscylował wokół $170 \mathrm{~cm}$ lub niewiele więcej.

${ }^{11} \mathrm{~W}$ polskim tłumaczeniu I. i T. Zawadzkich fragment ten brzmi: „po oberwanych kończynach zieją otworami ogromne jaskinie. Wewnątrz widać olbrzymie głazy, których ciężarem twórca obciążył posąg u podstawy", Pliniusz, Historia naturalna (wybór), t. II, Wrocław 2004, s. 309.

12 Strabon, Geographica, XIV, 2, 5 (wyd. $z$ tekstem oryginalnym i tłumaczeniem angielskim H.L. Jones'a, Cambridge, Mass.-London 1960).

13 Pani prof. dr hab. Krystynie Bartol z UAM dziękuję za konsultację tekstów źródłowych. 
Jeden z epigramatów pomieszczonych w Anthologia Graeca ma formę dedykacji Kolosa Rodyjskiego ${ }^{14}$. Potwierdza ona, że brązowy (chalkeon) Kolos wznieśli mieszkańcy wyspy „do Olimpu” (pros Olympon) po zażegnaniu niepokojów wojny i z łupów, które ona im przyniosła. Następny zwrot trzeba przytoczyć in extenso: ou gar hyper pelagous monon anthesan, alla kai en ga, co dosłownie można przetłumaczyć: [wznieśli] przecież nie tylko nad morzem, lecz i na ziemi. Dalej następują podniosłe słowa o świetle wolności i predestynacji heraklejskiego rodu Rodyjczyków do panowania na morzu i lądzie. Zwraca uwagę, że użyto słowa hyper dla morza, lecz en dla ziemi, co może mieć znaczenie dla naszych dalszych rozważań odnośnie do lokalizacji Kolosa, choć, oczywiście, jest to utwór poetycki i tego rodzaju różnic nie należy przeceniać15.

Przejdźmy teraz do streszczenia tekstu Filona z Bizancjum ${ }^{16}$. Najpierw autor potwierdza 70-łokciową wysokość rzeźby. Następne zdanie jest zastanawiające, wynikałoby bowiem z niego, że identyfikacja wizerunku jako Heliosa była możliwa monois [jedynie? dlaczego?- uwaga moja] na podstawie „symboli”, pod którym to pojęciem należy rozumieć jakieś atrybuty czy rekwizyty (he gar eikon tou theou symbolois egignosketo tois eks ekeinou) ${ }^{17}$. Artysta zużył tak wiele metalu, że niemal wyczerpał jego zasoby [w tekście użyto słowa chalkos, które oznacza przede wszystkim 'miedź', ale także 'brąz' i wszelki stop z udziałem miedzi]. Tak więc było to brązowe dzieło całego świata (to gar choneuma tou kataskeuasmatos egeneto chalkourgema tou kosmou). W następnym ustępie godny uwagi jest zwrot sugerujący pracę przy wizerunku boga kolejno nadkładanymi warstwami (ten eikona tou theou tais epibolais apo ges eis ton ouranon anabibazontes). Dalej o konstrukcji wewnętrznej posągu i jest to jeden z najbardziej dyskusyjych fragmentów; przytoczę najpierw słowa oryginału, gdyż wartość semantyczna słów schediais i mochlois może być bardzo różnie tłumaczona: schediais siderais kai tetrapedois diesfalisato lithois, hon hoi diapeges mochloi kyklo-

${ }^{14}$ J. Overbeck, Die antiken Schriftquellen zur Geschichte der bildende Künste bei den Griechen, Leipzig 1868, nr 1543.

${ }^{15}$ Nie można przemilczeć, że zwrot retoryczny o władztwie „na ziemi i morzu” pojawił się w okresie hellenistycznym jako jeden ze środków gloryfikacji przede wszystkim władców, niemający odniesień do konkretnych sytuacji. Na ten temat zob. A. Momigliano, „Terra Marique”, „Journal of Roman Studies” 1942, 32, s. 53-64, w szczególności s. 55, gdzie omawiany jest wskazany epigram.

16 Philo Byzantinus, de septem orbis spectaculis, graece cum versione latina..., red.

J.C. Orelli, Lipsiae 1816, miraculum IV, tekst grecki s. 14-18, łaciński s. 15-19.

17 Ostatnie słowo cytatu może być rozumiane różnie. 
pion emfainousi raisterokopian. W każdym razie chodzi tu o jakieś żelazne sztangi lub ruszt, który wraz z kamiennymi ciosami stabilizował całość, a mochloi to najpewniej łączniki. Ta wewnętrzna konstrukcja, według pisarza, przypomina dzieło wykute młotami przez Cyklopów i jest bardziej godna podziwu niż zewnętrzna. Jakimiż to szczypcami, na jakich kowadłach, jakiej siły potrzeba było, aby odkuć tak ciężkie pręty (ton obeliskon echalkeuthe)? [obeliskos to zasadniczo 'rożen'. To prawda, ale do zbrojenia nie używa się rożnów. W każdym razie, w obu przypadkach jest to żelazny pręt o niewielkim przekroju poprzecznym].

W następnym akapicie (IV, 3) mowa o bazie z białego, przypominającego marmur kamienia, w której artysta zamocował (èreise) nogi posągu aż do wysokości kostek. Już na tym etapie uwzględniał proporcje (symmetria) całej postaci. Filon mówi, że sama długość stopy była większa niż wysokość innych posągów antropomorficznych ${ }^{18}$. Partie wyższe trzeba było wykonywać inaczej: epichoneuein d'edei ta sfyra, podobnie jak wznosi się dom, co, naszym zdaniem, należy tłumaczyć: dodawano kolejne wyższe partie posągu odkute młotem, tak jak kolejne warstwy muru ${ }^{19}$.

Artyści [w liczbie mnogiej, a więc liczni pomocnicy] modelowali (plassousi) posąg, następnie odlewali (choneuousin) człon po członie i w końcu całość łączyli (holous synthentes). Po odlaniu jednej części formowali drugą, a gdy ta była zrobiona (chalkourgèthenti), nadbudowywano (epidedōmētai) trzecią. Cały czas pracowano tą metodą. „Nie można było przecież przemieszczać metalowych członów” (ou gar enēn ta melē tōn metallōn kinēsai).

Po skończeniu odlewu na przedtem ukończonej robocie dbano o właściwy rozstaw sztang (tōn mochlōn) i połączenia prętów (pēgma tēs schedias), a wkładanymi kamieniami zabezpieczano przeciwwagę (sēkoma). Wokół jeszcze nieukończonej części Kolosa każdorazowo nadsypywano potężne obwałowanie ziemne, zakrywając tym samym partie już wykonane. Dzięki temu z równego poziomu można było wykonywać następną część odlewu.

${ }^{18}$ Już chociażby te słowa powinny przestrzegać przed zbyt dosłownym braniem podawanych przez niego informacji. Z retorycznego punktu widzenia musiał mieć na myśli chyba posągi naturalnej wielkości, powiedzmy ok. 1,80 m. Jeśli stopa w przybliżeniu jest 1/6 wysokości całego ciała, to całe ono miałoby 10,80 m wysokości, a więc trzykrotnie mniej niż podawane w źródłach wymiary Kolosa. Gdyby Filon widział te ślady, tego rodzaju porównanie nie przyszłoby mu do głowy. Podawał więc bezkrytycznie informacje kompilowane zapewne z różnych źródeł.

19 Vedder, Der Koloss..., s. 83, a wcześniej także niektórzy inni autorzy, przyjmuje dosłownie epichoneuma jako nadlewanie kolejnych partii brązu. 
Filon podaje także (IV, 6), ile metalu zużyto do wykonania dzieła: 500 talentów brązu i 300 talentów żelaza. Gdyby przyjąć do przeliczenia talent attycki $(26,22 \mathrm{~kg})$, to byłoby to ok. 13,11 tony brązu i 7,87 tony żelaza. Ale w okresie hellenistycznym popularny był także talent aleksandryjski $(43,66 \mathrm{~kg})$ i nie wiadomo, który Filon miał na myśli, a przede wszystkim owe okrągłe liczby zdaje się mają znaczenie raczej retoryczne niż faktyczne albo też autor przepisał je $z$ jakiegoś innego dzieła.

Scholiasta do Fileba Platona mówi, że upadający Kolos pogruchotał wiele domów (oikias). Gdy król (Ptolemeusz) chciał go podnieść (anastēnai), Rodyjczycy obawiali się, aby nie przewrócił się ponownie ${ }^{20}$.

Podobną informację podaje Polibiusz (V, 88 n.), jednocześnie dając wskazówkę co do czasu katastrofy: było to na krótko przed bitwą pod Rafią, która miała miejsce w roku 217 przed Chr. ${ }^{21}$ Trzęsienie ziemi zwaliło także większą część murów miasta i urządzenia portowe. Ptolemeusz oferował, według tego autora, trzy tysiące talentów, stu budowniczych i trzystu pięćdziesięciu pomocników ${ }^{22}$.

Sekstus Empiryk opowiada historyjkę znacznie mniej wiarygodną, wszakże będącą dowodem legendy, jaką obrastał rodyjski cud świata poprzez starożytne wieki23 ${ }^{23}$ Mieli ją opowiadać sami Rodyjczycy: kazano Charesowi sporządzić kosztorys przyszłego dzieła. Gdy go przedstawił, zapytali, ile kosztowałby posąg dwukrotnie większy. On podał podwójną sumę, która stała się podstawą kontraktu. Chares jednak przeliczył się. Całą sumę wydał już na wstępnych etapach pracy i zdesperowany tym rzekomo odebrał sobie życie. Inni fachowcy obliczyli, że trzeba było nie dwu-, lecz ośmiokrotnej sumy. Biorąc pod uwagę, kiedy żył autor (II/III w.), wartość historyczna opowiedzianej przez niego anegdoty jest oczywiście wątpliwa, niemniej kłopoty z precyzyjnym kosztorysem tak nietypowego dzieła rzeczywiście mogły mieć miejsce ${ }^{24}$.

$20140 \mathrm{C}$; wykorzystano <http://home.arcor.de/angelion/koloss/kanhang.html>, [dostęp: 2 marca 2016]. Zob. też Overbeck, op. cit., nr 1553.

${ }^{21}$ Miejscowość na wybrzeżu palestyńskim, niedaleko Gazy. Antioch Wielki poniósł tu klęskę z ręki Ptolemeusza IV Filopatora.

22 Polibiusz, Dzieje, V, 88-89 (tłum. S. Hammer, t. I, Wrocław 1957; wykorzystano też tłum. francuskie P. Pédech'a, Paris 1977).

23 Sekstus Empiryk, Pros mathēmatikous, VII, 107 n. (w: Overbeck, op. cit., nr 1545).

${ }^{24}$ Koszt przeciętnego (naturalnej zapewne wielkości) posągu niewątpliwie szacowano prawidłowo. W czasach Diona Chryzostoma (ok. 40-115 r.) kosztował on 500-1000 drachm, Dio Chryzostom, Mowy, XXXI, 59 (wykorzystano wydanie z tłumaczeniem angielskim J.W. Cohoon, H. Lamar Crosby, III (mowy XXXI-XXXVI), Cambridge, Mass., 
Niektóre źródła mówią o ostatnich uchwytnych losach Kolosa Rodyjskiego. Bizantyjski historyk Malalas (pisał w pierwszej połowie VI wieku) podaje, jakoby cesarz Hadrian zamierzał podnieść (użyto tu słowa anēgeire, co można też tłumaczyć 'wzbudzić') posąg, który przez 342 lata leżał na ziemi (keimenon chamai) i nic z niego nie przepadło. Próbował go postawić w jego własnym miejscu. Wydał 300 tysięcy sestercji na maszynerię, liny i robociznę, co miało być uwiecznione inskrypcją umieszczoną „u dołu”25.

Konstantyn VII Porfirogeneta (905-959) opowiada, jak to Arabowie pod dowództwem Mawiasa (Muawija) zajęli Rodos²6 i zburzyli Kolosa po 1360 latach jego istnienia. Destrukty, wystawione na sprzedaż w Syrii, kupił żydowski handlarz z Edessy i obładował nimi 900 wielbłądów ${ }^{27}$. Brązowy ten posąg przedstawiał Heliosa, był pozłacany od stóp do głów, wysokości 80 łokci, a jego szerokość odpowiadała wysokości (platos analogōs), jak o tym świadczy napis na bazie stóp. Tam też jest podane imię twórcy: Laches $z$ Lindos.

Żyjący w XII wieku autor zwany Michałem Syryiczykiem wysokość Kolosa określa na 107 stóp oraz podaje, że był on postacią stojącą, wykonaną $z$ brązu korynckiego, a ta druga informacja chyba raczej dlatego, że owa legendarna odmiana brązu była synonimem najwyższej jakości. Gdyby jego przekaz potraktować dosłownie, należałoby przyjąć, że w czasie plądrowania Rodos przez Arabów Kolos jeszcze stał, ponieważ najeźdźcy rabując go, użyli lin. Co więcej, mieli rzekomo podłożyć pod posąg ogień i wtedy ujrzeli, że był on przytwierdzony żelaznymi ryglami do kamieni umieszczonych w zie$\mathrm{mi}^{28}$. Jest to źródło późne, a zatem też mało wiarygodne, ale przecież niejedyne uzasadniające hipotezy o restytucji posągu po 227 roku przed Chr., ale jeszcze w czasach starożytnych ${ }^{29}$.

1951). Warto przypomnieć, że ta najdłuższa z zachowanych mowa Diona była adresowana do Rodyjczyków.

25 Jan Malalas, Chronographia, XI, 279, 14.

${ }^{26} \mathrm{~W}$ roku 653 Konstantyn Porfirogeneta, de administrando imperio, 21 (Overbeck, op. cit., $\mathrm{nr}$ 1554).

${ }^{27}$ Niewiele niżej pisze, że było to 980 wielbłądów.

${ }^{28}$ Oryginalny tekst jest napisany w języku syryjskim (non vidi). Wykorzystuję tutaj Vedder, Der Koloss..., s. 21 i przyp. 57, z odnośnym fragmentem w tłumaczeniu niemieckim i angielskim L.I. Conrada, The Arabs and the Colossus, "Journal of the Royal Asiatic Society" (seria III), 1996, 2(6), s. $165 \mathrm{nn}$.

${ }^{29} \mathrm{~W}$ powyższym krótkim przeglądzie źródeł pominięto te, które nic ciekawego nie wnoszą do dyskutowanych tu problemów. Są to albo standardowe wzmianki o Kolosie jako jednym z siedmiu cudów świata, o jego wysokości itp., albo retoryczne gloryfikacje. 


\section{MIEJSCE USTAWIENIA KOLOSA RODYJSKIEGO}

Nawet jeszcze dziś w wielu popularnych opracowaniach chętnie powtarza się pogląd, jakoby Helios Charesa stał okrakiem nad wejściem do portu miasta Rodos, nie zwracając uwagi na to, jaka jest to odległość (il. 1). Według podawanych przez źródła starożytne wysokości posągu, na ogół 70 łokci, czyli 32-35 m, i zakładając prawidłowe jego antropomorficzne proporcje, rozstaw pomiędzy molo a nadbrzeżem jest około dwukrotnie za duż ${ }^{30}$, aby to było możliwe (albo Kolos musiałby mieć wysokość dwukrotnie większą niż 70 łokci). Zupełnie też nikt z powtarzających to bałamuctwo nie bierze pod uwagę, że podobne upozowanie wizerunku boskiego musiałoby wydawać się starożytnym Grekom cokolwiek niestosowne ${ }^{31}$. Co do statyki wystarczy napomknąć tylko tyle, że musiałby być dla tego rodzaju konstrukcji trzeci punkt podparcia (bez niego wiatr szybko przewróciłby posąg), a mógłby on być zamocowany jedynie pod wodą, przeszkadzając statkom wchodzącym do portu ${ }^{32}$. W żadnym ze źródeł starożytnych o tego rodzaju ustawieniu Kolosa nie czytamy. Średniowieczne pochodzenie tej legendy dobrze przedstawiła U. Vedder. Najstarsza znana dotąd odnośna wzmianka pochodzi od pielgrzyma Nicolasa de Martoni, z roku 1394. Opowiedziano mu, że jedna noga Kolosa znajdowała się na końcu mola, tam, gdzie w czasach tego włoskiego podróżnika stał kościół pw. św. Mikołaja (a do dziś stoi fort zbudowany na jego miejscu i pod tym samym wezwaniem), a druga - na końcu drugiego mola, na którym znajdują się wiatraki ${ }^{33}$. Autor wie, że odległość

30 A. Gabriel, La construction, l'attitude et l'emplacement du colosse de Rhodes, „Bulletin de Correspondance Hellénique” 1932, 56, s. 349, przyp. 5, szacuje, że rozstaw stóp przy takiej pozie musiałby przekraczać $400 \mathrm{~m}$. Dzisiejsze wejście do portu Mandraki ma ok. $70 \mathrm{~m}$ pomiędzy najbardziej wysuniętymi punktami mola przy forcie św. Mikołaja i przeciwległego nabrzeża (Platoni). Podobnie zapewne było w starożytności; przy rozstawie $400 \mathrm{~m}$ praktycznie niemożliwe byłoby naciągnięcie łańcucha, którym zabezpieczano wówczas porty przed wpłynięciem jednostek nieprzyjacielskich. Tak duże rozstawy także nie występują przy wejściach do pozostałych portów miasta, tym bardziej że są one większe niż w Mandraki. Gabriel myślał o odległości między fortem św. Mikołaja a molem po wschodniej stronie obecnego portu handlowego, gdzie również znajdowały się wiatraki. Te dwa punkty jednak nie tworzą wejścia do portu. Autor oczywiście odrzucał tę odległość pomiędzy stopami posągu jako absurdalną.

${ }^{31}$ K.F. Lüders, Der Koloss von Rhodos, Hamburg 1865, s. 1, żartuje, że Kolos musiałby spoglądać na przepływających między jego nogami jak na Pigmejów.

${ }^{32} \mathrm{~Np}$. kamuflowany jakąś włócznią lub czymś podobnym, pomijając fakt, że nie był to typowy atrybut Heliosa, o czym niżej.

${ }^{33}$ Faktycznie wszystkie te obiekty budowlane stoją na molo po wschodniej stronie portu Mandraki. Zachowane do dziś wiatraki są niewątpliwie poźniejsze, lecz stawiano je zawsze na tym dobrze wystawionym na wiatr miejscu. 


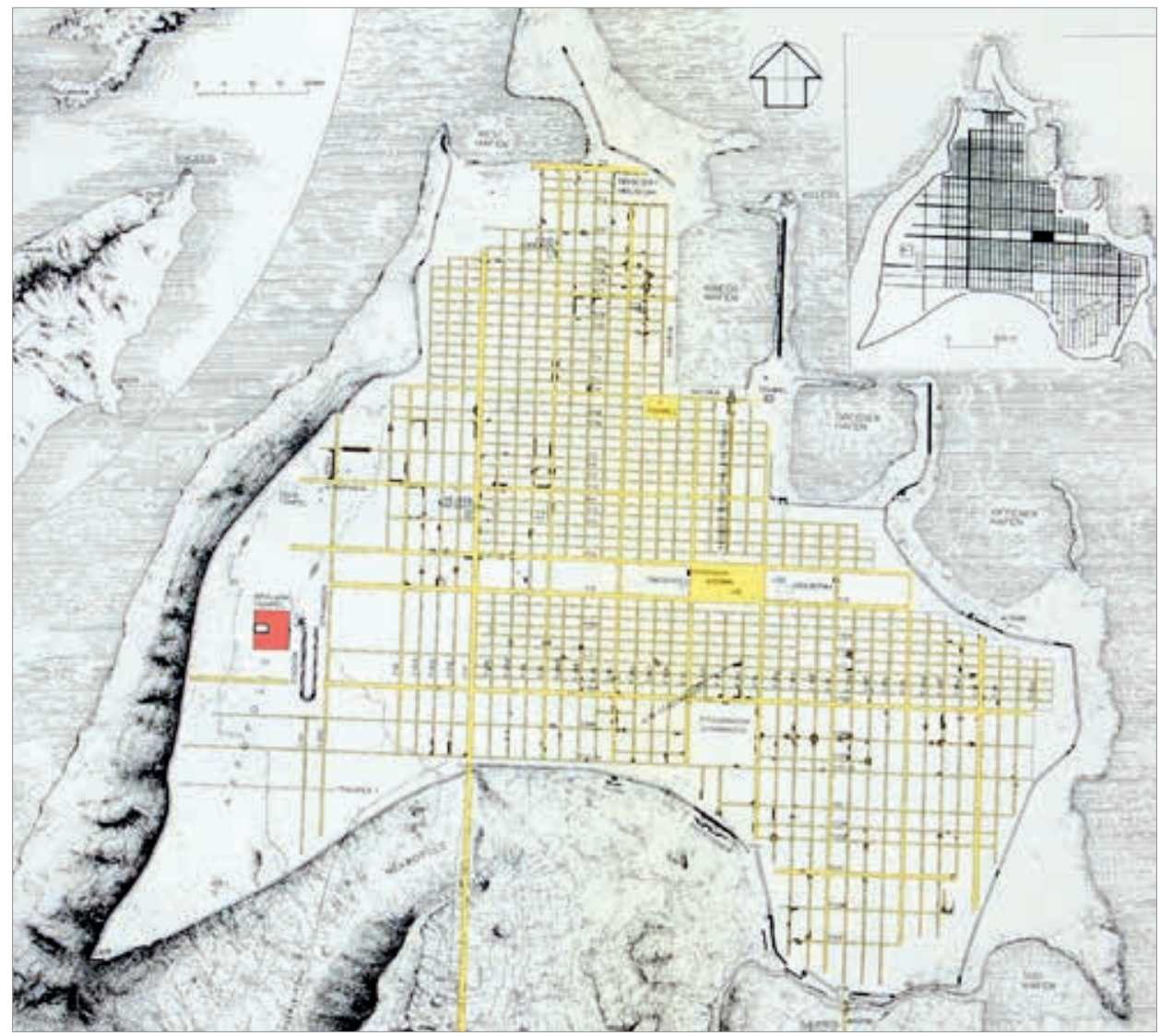

1. Rekonstrukcja planu antycznego miasta Rodos. Zaznaczono sugerowane miejsce ustawienia Kolosa Rodyjskiego na akropoli (wg Geschichte des Wohnens, I, red. W. Hoepfner, Stuttgart 1999, wklejka nr 2)

pomiędzy wskazanymi punktami to tysiąc kroków, ale zdaje się nie wyciąga z tego żadnych implikacji co do wysokości posągu. Jeszcze bardziej fantastyczna jest wiadomość, że ten, kto wdrapał się [w jaki sposób?] na głowę Kolosa, widział horyzont w zasięgu stu mil ${ }^{34}$.

W roku 1480, roku pierwszego oblężenia Rodos przez Turków, joannita Wilhelm Caoursin lokalizuje legendarnego Kolosa w miejscu fortu św. Mikołaja (zbudowanego w początkach XV wieku), nic nie mówiąc o pozie w roz-

${ }^{34} \mathrm{Na}$ niepodobieństwo pozy w rozkroku wskazywał już znany podróżnik i erudyta osiemnastowieczny M.G.A.F. de Choiseul-Gouffier, Voyage pittoresque de la Grèce, I, Paris 1782, s. 108. 
$k$ roku $^{35}$. I ten pogląd do dziś ma swoich zwolenników. Trzecią hipotetyczną lokalizację niektórzy badacze sytuują gdzieś dalej w mieście Rodos, na przykład w obrębie sanktuarium Heliosa lub na miejscu obecnego pałacu Wielkich Mistrzów joannickich. Wreszcie czwartym domniemanym miejscem wystawienia Kolosa jest akropola miasta lub jej podnóże ${ }^{36}$.

Rozpatrzmy najpierw tę lokalizację, która ma przynajmniej niektóre cechy prawdopodobieństwa, a więc ustawienie rzeźby u końca mola w zatoce Mandraki. Molo ma kierunek N-S, jego koniec jest od północy. Tę lokalizację preferował A. Gabriel, za nim przyjęła M.L. Bernhard ${ }^{37}$, stosunkowo niedawno także W. Hoepfner ${ }^{38}$.

Molo jest dość wąskie, co prawda nie aż tak, żeby na jego końcu nie mógł zmieścić się posąg stojącego mężczyzny nawet kolosalnych rozmiarów, niemniej jednak byłby to front robót dla wieloletniego przedsięwzięcia (w sumie 21 lat, w tym prawdopodobnie 12 bezpośredniego wykonawstwa in situ) bardzo ograniczony. Tym bardziej niedogodne byłyby drogi transportu materiałów (długość mola obecnie ok. $400 \mathrm{~m}$ ). Nadto prace przy posągu wyłączałyby lub poważnie ograniczały użytkowanie mola do celów związanych z funkcjonowaniem portu. Naszym zdaniem, jednak najbardziej przeciw tej lokalizacji przemawiają nie do rozwiązania trudności z właściwym, godnym ustawieniem Kolosa względem stron świata. A limine można odrzucić ustawienie posągu twarzą ku północy lub twarzą ku wschodowi. W obu tych przypadkach bóg odwróciłby się plecami do miasta, tak jakby ignorował swoje dziedzictwo (Rodos, według mitologii, była wyspą Heliosa) ${ }^{39}$. Poza tym, przy tego rodzaju ustawieniach, wąskości mola, a co za tym idzie - skrajnie żabiej perspektywie, mieszkańcy miasta nie mogliby podziwiać twarzy bóstwa $z$ bliska, a $z$ daleka co najwyżej od południowego wschodu, i to pod bardzo ostrym kątem.

35 Vedder, Der Koloss..., s. 13, 16, 72 n.

36 Vedder (ibidem, s. 17) przywołuje opinię z publikacji w języku japońskim K. Sengoku (non vidi), według której Kolos Rodyjski stał u podnóża akropoli, tam, gdzie dziś znajduje się zrekonstruowany stadion.

37 Gabriel, op. cit., s. 350 nn.; M.L. Bernhard, Sztuka hellenistyczna, Warszawa 1993, s. $215-220$.

38 W. Hoepfner, Der Koloss von Rhodos, „Archäologischer Anzeiger“ 2000, 1, s. 129153. Tezy powtórzone w: idem, Der Koloß von Rhodos und die Bauten des Helios. Neue Forschungen zu einem der Sieben Weltwunder, Mainz 2003.

39 Aczkolwiek Hoepfner, Der Koloss von Rhodos..., s. 145, tak właśnie to widzi: Kolos od tyłu był opromieniany słońcem, z miasta było widać jego tył i bok; w tamtych czasach, jak argumentuje, widok od tyłu nie był postrzegany jako gorszy [!]. G. Konstantinopoulos (non vidi), do którego odwołanie ibidem, s. 145, przyp. 28, miał podobne zastrzeżenia jak my. 
Jedyny właściwie argument, który można by wysunąć dla tych ustawień, to to, że wówczas posąg boga jakby własnymi plecami osłaniałby miasto. Niektórzy badacze na podstawie pewnego reliefu z czasów rzymskich przyjmują, że Helios dłonią przysłaniał oczy, jakby badał horyzont ${ }^{40}$, i wtedy dyskutowane tu ustawienie miałoby sens, ale koncepcja ta jest nieprawdopodobna chociażby ze względów statycznych.

Gdyby zaś posąg ustawiono twarzą ku południu lub ku zachodowi, to wówczas, co prawda, spoglądałby on na swoje miasto, ale byłby plecami odwrócony do nadpływających do portu okrętów, a więc fatalny omen! A Rodyjczycy żyli głównie z morza i radzi by wszystkich ściągnąć do swoich portów, zapraszać, a nie odstraszać. Jedynie ustawienie twarzą ku zachodowi mogłoby mieć pewien walor prawdopodobieństwa, ponieważ wtedy bóg byłby widziany na tle wschodzącego słońca, z którym był tożsamy. Ale takie ustawienie właściwsze byłoby dla kwadrygi Heliosa, wzbijającej się w niebo, a nie dla postaci stojącej. Oczywiście można by rozważać także ustawienia pośrednie pomiędzy kierunkami kardynalnymi, ale nie usunęłoby to aporii scharakteryzowanych wyżej. Należy pamiętać, że Grecy byli uczuleni na tego rodzaju niuanse ${ }^{41}$.

Wreszcie przeciwko ustawieniu Kolosa na końcu mola przemawia fakt, że byłoby to przy wejściu do portu wojennego ${ }^{42}$. To prawdopodobnie do tego portu nie wolno było nikomu (sc. niepowołanemu) wchodzić, ani nawet interesować się nim, zakaz niewątpliwie ustanowiony z obawy przed szpiegostwem lub dywersjąa ${ }^{43}$. Jak w takiej sytuacji można by myśleć o rozsławieniu dzieła jako jednego $z$ cudów starożytnego świata?

Przeciw tej lokalizacji przemawiają także informacje, jakoby destrukty Kolosa leżały przez kilkaset lat nieruszone, w miejscu, gdzie rzeźbę zwaliło trzęsienie ziemi. Przy wejściu do portu stanowiłyby przecież poważne utrudnienie, a nawet niebezpieczeństwo, jako że bardziej prawdopodobne jest, że przechyliły się do wody niż w kierunku wąskiego paska lądu ${ }^{44}$. Ponadto, czy

40 B.S. Ridgway, Hellenistic Sculpture, I, The Styles of ca. 331-200 B.C., Bedminster/ Bristol 1990, s. 210. Autorka ta ostrożnie przyimuje, że Kolos stał w mieście, w pobliżu wody.

${ }^{41}$ Por. H. von Steuben, Griechische Statuen unter freiem Himmel, „Städel-Jahrbuch“, N.F., 1999, 17, s. 7 nn.

${ }^{42}$ Miasto Rodos w starożytności posiadało aż cztery (właściwie nawet pięć) zatoki portowe. Trzy z nich, po wschodniej stronie cypla, na którym miasto założono, przetrwały do dziś, a poczynając od północy były to porty: wojenny, wielki i otwarty. Na wybrzeżu zachodnim była zatoka portowa, obecnie zasypana, mniej więcej pomiędzy obecnymi ulicami Papanikolaou, Iroon Politechniou i Mandilara.

43 Strabon, XIV, 2, 5 (C 653).

${ }^{44}$ Por. Lüders, op. cit., s. 14. 
po upływie kilkuset lat żelazne elementy wewnętrznej konstrukcji byłyby nadal tak mało skorodowane, że oglądający z łatwością je identyfikowali?

Gdyby Kolos stał na molo, nie byłby widoczny dla okrętów płynących w kierunku wyspy od strony południowo-zachodniej, ponieważ od tej strony dolne miasto przysłania masyw akropoli (obecnie nazywanej Wzgórzem Smitha, wcześniej Świętego Stefana) ${ }^{45}$.

Podobnie byłoby, gdyby Kolos został ustawiony w rejonie późniejszego pałacu Wielkich Mistrzów. Leży on na łagodnym wyniesieniu, niższym niż Monte Smith, aczkolwiek dobrze widocznym z portów i niższych rejonów miasta. Tę lokalizację uznało za prawdopodobną kilku uczonych, mając na swoje poparcie argument toponomastyczny. W tym bowiem miejscu w średniowieczu znajdowała się kaplica pw. św. Jana, nazywana w źródłach fanum Sancti Joannis Colossensis ${ }^{46}$. Gabriel zwrócił jednak uwagę, że jako colossensis był określany także miejscowy arcybiskup, a co za tym idzie - także jego kościól, a Rodyjczycy byli określani niekiedy jako Colossenses, niewątpliwie pod wpływem legendy starożytnego cudu świata ${ }^{47}$. Zatem określenie "kolosalny” byłoby niekiedy synonimem słowa „rodyjski”. Można ponadto wątpić, czy w tak cennym miejscu miasta (między agorą a portem) pozostawiano by destrukty rzeźby nieruszane przez kilkaset lat.

To samo można powiedzieć o kolejnej propozycji lokalizacji Kolosa na terenie sanktuarium Heliosa, zidentyfikowanego na narożniku ulic P 27 i P 13 miasta starożytnego (dziś jest to rejon ulicy Sofouli w pobliżu skrzyżowania $z$ ulicą Chimaras ${ }^{48}$. Miejsce to jednak jest niezbyt eksponowane, a samo

45 Miasto Rodos przyrównywano do theatronu, gdyż rzeczywiście od południowego zachodu jest otoczone skałą jakby kolistą widownią teatru greckiego. To ukształtowanie było malownicze, ale też kłopotliwe, ponieważ po gwałtownych deszczach miasto było zalewane spływającą wodą i błotem. $Z$ tego powodu wykonano kolektory, funkcjonalnie podobne do dzisiejszych burzowców, których relikty częściowo są zidentyfikowane, zob. Diodor, XIX, 45; XX, 83.

46 L. Ross, Reisen auf den griechischen Inseln des ägäisches Meeres, III, Stuttgart-Tübingen 1845, s. 86, rozważał lokalizację przy którymś z „kanałów” otaczających seraj paszy, czyli dawny pałac Wielkich Mistrzów, choć nie byłoby to, jak zauważa, odpowiednie miejsce. W każdym razie nazwanie kaplicy wiąże z Kolosem, który musiał stać gdzieś w porcie, s. 87; Lüders, op. cit., s. 14. Na miejscu pałacu Wielkich Mistrzów sytuowali Kolosa także L. Morricone, I sacerdoti di Halios. Frammento di catalogo rinvenuto a Rodi, „Annuario della R. Scuola Archeologica di Atene" 1949-1951 (wyd. 1952), XXVII-XXIX (N.S. XI-XIII); Charles P., Bulletin archéologique. Sculpture, statuaire du IV-e s. à la fin de l'ère hellénistique. III. Époque hellénistique, „Revue des Études Grecques” 1943, 56 (264-265), s. 229.

47 Gabriel, op. cit., s. 349 i przyp. 3; podobnego określenia używali Bizantyjczycy.

${ }^{48}$ W. Hoepfner i in., Die Epoche der Griechen, w: Geschichte des Wohnens, I, 5000 v.Chr. -500 n.Chr. Vorgeschichte, Frühgeschichte, Antike, Stuttgart 1999, s. 293. 
sanktuarium zajmowało stosunkowo niewielki obszar. Trzeba także brać pod uwagę, że gdzieś w Rodos musiała stać słynna Kwadryga Heliosa Lizypa ${ }^{49}$, o ile rzeczywiście były dwie repliki tej rzeźby ${ }^{50}$. Nie była ona tak monumentalnych rozmiarów jak Kolos, niemniej jednak wątpliwości mogą się nasuwać podobne jak wyżej, a mianowicie co do ustawienia rzeźby. Kwadryga słońca powinna sugerować ruch od wschodu, ale wtedy we wspomnianym sanktuarium stałaby tyłem do miasta, ponieważ znajdowało się ono w zachodniej jego części, dość daleko od portów. Miejsce to nie wydaje się odpowiednie dla żadnej z tych dwóch słynnych rzeźb. Gdzie ona jednak stała w Rodos, trudno powiedzieć. Prawie na pewno nie na akropoli, gdyż ekspozycja Kwadrygi Słońca ma sens, jeśli jest ona usytuowana na tle wschodzącego słońca, jakby wynurzająca się $z$ morza. Ergo, na akropoli musiałaby stać tyłem do miasta. Jeśli rzeczywiście była w Rodos, stała raczej w którymś z sanktuariów w dolnym mieście, może blisko wschodniego wybrzeża. W mieście mogło być więcej niż jedno sanktuarium głównego boga wyspy, poza miastem oczywiście także było ich wiele ${ }^{51}$.

Akropola znajduje się w południowo-zachodniej części miasta i jest miejscem wyróżniającym się w krajobrazie.Od czasów wojen napoleońskich jest określana mianem Monte Smith. Przeprowadzone wykopaliska archeologiczne $^{52}$ ujawniły na jej obszarze relikty świątyni doryckiej określanej jako poświęcona Apollinowi, u jej podnóża odeon, gimnazjon i dalej na południe - stadion. W pewnej odległości na północ od świątyni Apollina zidentyfikowano świątynię Zeusa, nimfeum, domy mieszkalne. W sumie reliktów architektonicznych jest całkiem sporo, lecz funkcja nie wszystkich została ustalona.

49 Pliniusz XXXIV, 63.

${ }^{50}$ Nie ma wątpliwości, że jedna z nich stała w Delfach, natomiast czy druga została wykonana dla Rodos i tam eksponowana - źródła nie dają jednoznacznej odpowiedzi. Wydaje się, że Rodyjczycy nie odmówiliby sobie dumy z posiadania tak słynnego dzieła. Po drugie, znana anegdota o półtora tysiącu dzieł wykonanych przez Lizypa w ciągu całego życia (Pliniusz XXXIV, 37) poza swoim retorycznym walorem może zawierać ziarno prawdy, jeśli przyjmiemy, że w pracowni mistrza wykonywano multiple jego dzieł. Por. Ridgway, op. cit., s. 58. Zob. też. D. Laroche, A. Jacquemin, Le char d'or consacré par le peuple rhodien, „Bulletin de Correspondance Hellénique” 1986, 1(110), s. 285 nn.

${ }^{51}$ Istnieją zabytki epigraficzne z Rodos, zawierające liczne imiona kapłanów Heliosa, zob. Morricone, op. cit., s. 351-380.

${ }^{52}$ Pierwsze wykopaliska przeprowadzono, gdy wyspa stała się własnością Włoch i na Monte Smith aranżowano zabudowania wojskowe. Wystąpiły liczne zabytki starożytne, zob. komunikat B. Pace, Scoperte archeologiche a Monte Smith, „Annuario della R. Scuola Archeologica di Atene" 1914, 1, s. 370. W latach międzywojennych odkryto świątynię i wykonano intensywne prace rekonstrukcyjne zespołu architektonicznego. Poprawkowe, bardziej systematyczne wykopaliska przeprowadzili badacze greccy po odzyskaniu Dodekanezu w roku 1948. 
W szczególności ważne jest to w odniesieniu do budowli w bezpośrednim sąsiedztwie świątyni Apollina. Nieco dalej na północny wschód od niej, poniżej akropoli, odkopano pozostałości warsztatów odlewających rzeźby z brązu ${ }^{53}$.

Akropole $z$ natury rzeczy były najważniejszymi z ideowego punktu widzenia częściami miasta greckiego. Tam sytuowano świątynie najbardziej czczonych bóstw i inne znaczące budowle; wystarczy odwołać się do powszechnie znanego przykładu Akropolu ateńskiego ze świątynią najpierw Ateny Polias, a później Ateny Dziewiczej (Partenon), patronki miasta i Attyki. Te zespoły architektoniczne były ponadto przedmiotem dumy mieszkańców i podziwu przybyszy. Dziwne zatem byłoby, gdyby w Rodos na tak szacownym miejscu nie było kultu Heliosa. Relikty doryckiego heksastylu w najbardziej eksponowanym miejscu wzgórza dotychczasowi badacze wiązali z kultem Apollina, Ursula Vedder z Heliosem. Miejsce ustawienia Kolosa widzi ona w bezpośrednim sąsiedztwie świątyni, w pobliżu jej północno-wschodniego narożnika (il. 2). Zachowane w tym miejscu relikty, niedostatecznie jak dotąd przebadane, uznała za pozostałości po fundamentowaniu bazy Kolosa, co nie przekonuje ${ }^{54}$. Natomiast sama idea jest słuszna. Gdyby Kolos stał w tym miejscu lub gdzieś w pobliżu na najwyższym poziomie akropoli, byłby spektakularnie widoczny zarówno z miasta, jak i z morza i - co istotne - także $z$ morza od strony południowo-zachodniej wyspy (il. 3). Sądzimy, że twarzą był skierowany na wschód lub lekko na północny wschód w kierunku miasta, które w ten sposób jakby miał pod sobą. Wówczas oczywiście byłby plecami odwrócony do morza od strony zachodniej wyspy. Jednak tutaj ewentualne negatywne konotacje takiego upozowania nie byłyby zbyt oczywiste. Akropola w tym miejscu wznosi się na ok. 90 m n.p.m., ale od strony zachodniej kończy się stromym urwiskiem (w prostej linii do brzegu morza jest tu ok. $130 \mathrm{~m})$. Także dziś od tej strony nie ma podejścia na wzgórze. U dołu wąski

${ }^{53}$ Ch. Kantzia, G. Zimmer, Rhodische Kolosse. Eine hellenistische Bronzegusswerkstatt, „Archäologischer Anzeiger“ 1989, 4, s. 499 nn. W sumie dotąd odkryto 6 warsztatów odlewniczych z czasów hellenistycznych, wszystkie zlokalizowane na wschód i północny wschód od akropoli. W jednym z nich zlokalizowano dół odlewniczy, największy ze znanych nam ze starożytności, ale żadnego nie można wiązać z Kolosem ze względu na jego rozmiary.

54 Vedder, Der Koloss..., s. 57 nn., il. 56-57. Pozostałości raczej wyglądają na jakąś budowlę z funkcją użytkową, są tam np. relikty cystern, aczkolwiek niewątpliwie miały miejsce wtórne przeróbki tego kompleksu. Gdyby jednak destrukty Kolosa leżały w tym miejscu rzeczywiście przez kilkaset lat, jak możliwe byłyby te przeróbki? Brak precyzyinego rozwarstwienia chronologicznego omawianych reliktów w dotychczasowych publikacjach nie pozwala na zajęcie stanowiska; trzeba pamiętać, że akropola była zabudowywana także w czasach tureckich. 


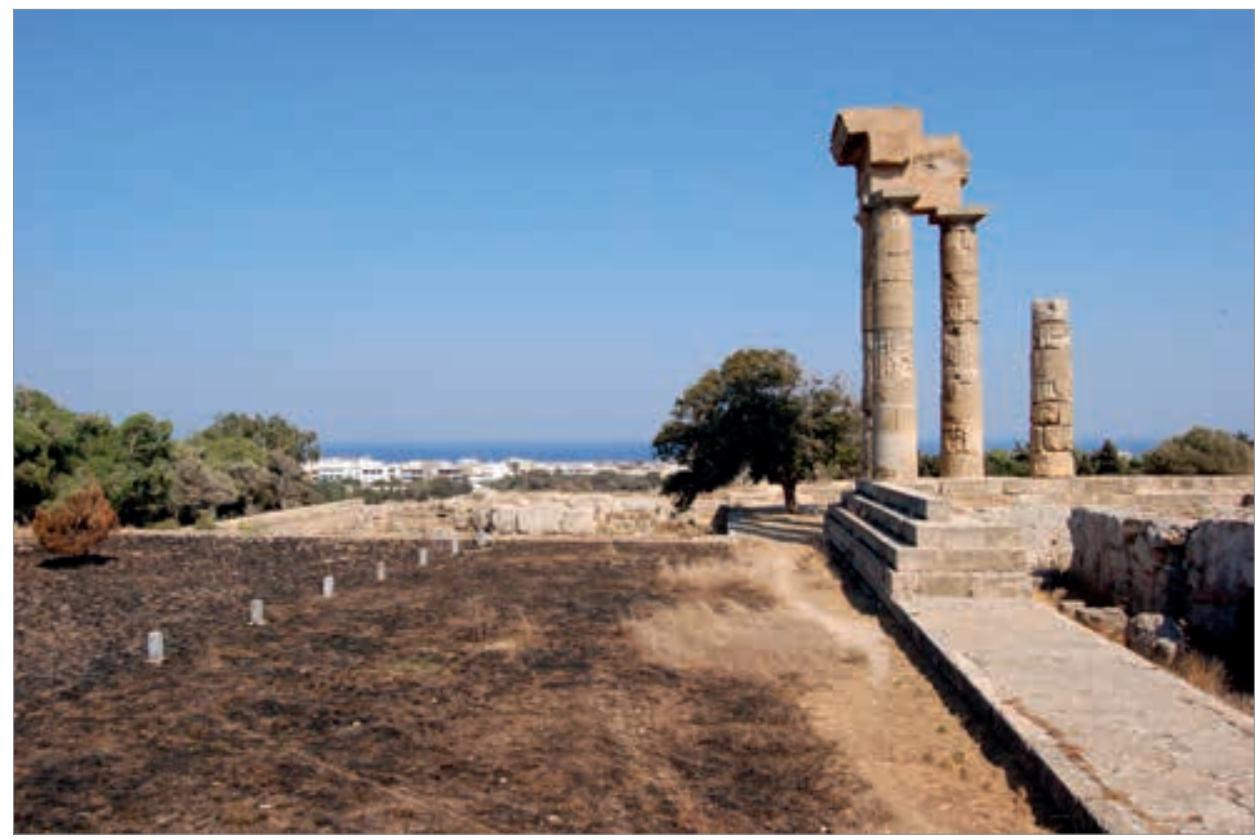

2. Częściowo zrekonstruowana świątynia na akropoli miasta Rodos. Na lewo od niej mógł stać Kolos Rodyjski. Na horyzoncie widoczne morze po wschodniej stronie wyspy. Fot. T. Wujewski

pasek lądu pozwolił w naszych czasach na poprowadzenie drogi w kierunku miejscowości na zachodnim wybrzeżu (także do starożytnego Kamejros), ale $z$ tego poziomu, ze względu na silny skrót, nie ma żadnej realnej perspektywy na zabudowania akropoli, co znaczy, że także Kolos byłby stąd praktycznie niezauważalny, nawet przy swoim ogromie. $Z$ morza natomiast, z pokładu podpływających od strony zachodniej statków, byłby pierwszym widocznym obiektem miasta, ale raczej jako świetlisty punkt niż wyraźnie postrzegana postać $^{55}$. Bowiem wokół głowy Heliosa najprawdopodobniej znajdowała się pozłacana corona radiata ${ }^{56}$. Być może od samego początku nawet cały brą-

55 Tu wracamy do wspomnianego wyżej epigramu z AG VI, 171. Nie odnosi się on zapewne do faktycznego miejsca ustawienia Kolosa na akropoli, jednakże świadomość funkcjonowania tego typu zwrotu retorycznego w ówczesnej kulturze („na ziemi i na morzu”) mogła wpłynąć na decyzję usytuowania rzeźby w tym właśnie miejscu.

${ }^{56}$ Jest to standard w ikonografii Heliosa, zob. Lexicon Iconographicum Mythologiae Classicae (= LIMC), red. generalna L. Kahil, Zürich-München 1990, IV, 1 (s.v. Helios - Sol, C. Letta), s. 592-625; IV, 2, s. 366-385; V, 1 (s.v. Helios, N. Yalouris i in.), s. 1005-1038; V, 2, s. 631-657. Na Rodos znaleziono kamienną głowę Heliosa, powszechnie uważaną za naśla- 


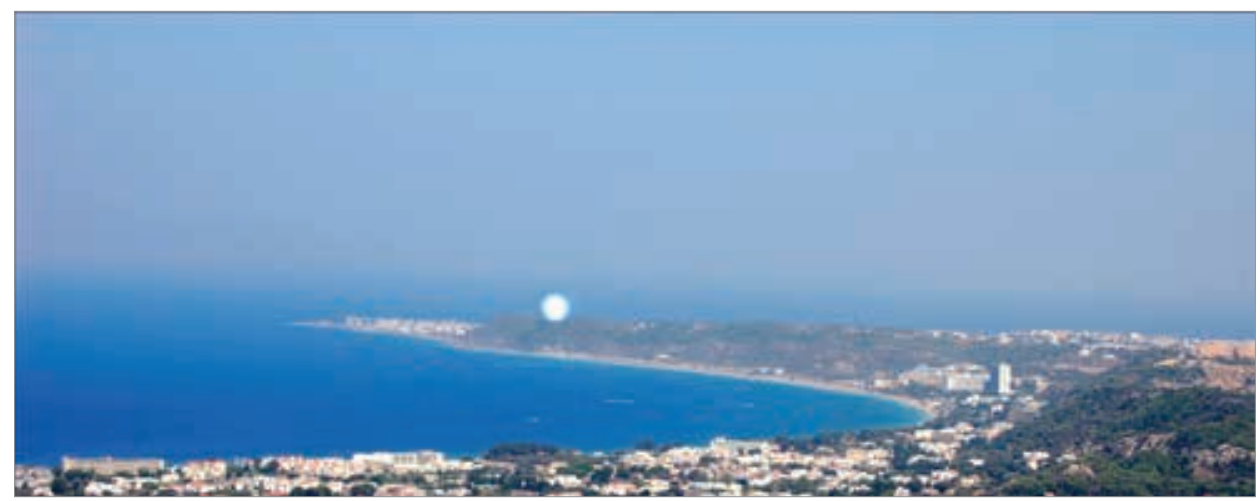

3. Panorama północnego cypla wyspy Rodos, widziana z antycznego Jalyssos (ob. Filerimos). Kropką zaznaczono miejsce, w którym mógł stać Kolos Rodyjski. Taki widok ukazywał się marynarzom podpływającym do wyspy od zachodu. Fot. T. Wujewski

zowy posąg był pozłacany, co w odniesieniu do bóstwa słonecznego byłoby szczególnie uzasadnione. Warto zauważyć, że podobne wrażenie wywoływał złocony grzebień Fidiaszowej Ateny Promachos w Atenach, a Kolos Rodyjski najwyraźniej powstał w okolicznościach emulacji Rodyjczyków z Ateńczykami w dziedzinie kultury ${ }^{57}$. Być może śladem owego świetlistego efektu są w późniejszej legendzie Kolosa opowiadania, jakoby pełnił on jednocześnie funkcję latarni morskiej ${ }^{58}$. (Gdyby tak było naprawdę, jedynym miejscem widocznym zewsząd z morza byłoby miejsce właśnie na akropoli!).

Kolos stojący w pobliżu świątyni musiałby być od niej znacznie wyższy ${ }^{59}$. Na pierwszy rzut oka relacja przestrzenna tego rodzaju może wydawać się

downictwo Charesowego Kolosa. W głowie są nawiercone otwory, w których były osadzone metalowe promienie, G.G. Konstantinopoulos, Das Archäologische Museum von Rhodos, Athen [b.r.wyd.], s. 60 n. Najczęściej wokół głowy Heliosa umieszczano siedem promieni.

${ }^{57}$ Przytoczona wyżej anegdota przekazana przez Sekstusa Empiryka wskazuje, że nie tyle Chares miał problemy z megalomanią, ile kierowani pychą Rodyjczycy chcieli dwukrotnie przewyższyć powstałe wcześniej słynne kolosalne rzeźby, przede wszystkim Fidiasza (Atenę Partenos, Atenę Promachos, może także Zeusa Olimpijskiego) i zapewne też Lizypa (Zeus z Tarentu). Faktem jest, że zadanie powierzyli uczniowi Lizypa.

${ }^{58}$ Helios miałby trzymać naczynie z płonącym ogniem, nawet gdzieś nad głową. Pomysł to absurdalny (na co zwrócił uwagę już Lüders, s. 12) przede wszystkim dlatego, że nie wiadomo, jak uzupełniano by paliwo. Przy tak wielkiej skali posągu teoretycznie można wyobrazić sobie schodki w jego wnętrzu (jak w posągu Bawarii w Monachium), ale miałoby to implikacje dla rekonstrukcji pozy i wewnętrznej konstrukcji dzieła.

${ }^{59}$ Relikty obecnej świątyni są z I w. przed Chr., lecz na jej miejscu już w IV w. istniała budowla o tej samej funkcji, może zresztą nawet niższa, por. Vedder, Der Koloss..., s. 35. 
pewną dysharmonią skal obu obiektów. Ale w sztuce greckiej zdarzały się podobne sytuacje. Jako znane przykłady można tu wymienić tzw. Tron Apollina w Amyklaj koło Sparty, dzieło Batyklesa z Magnezji, z ok. 530 r. przed Chr., i kolos obok Ojkosu Naksyjczyków na Delos. W pierwszym przypadku posąg boga (znacznie starszy niż czasy Batyklesa) był otoczony mniej więcej dwulub trzykrotnie niższą od niego budowlą, będącą w istocie rzeczy świadomie zaaranżowaną architektoniczną bazą i ramą dla rzeźby. Ta ostatnia była wykonana ze złota, jej wielkość była znaczna, choć oczywiście mniejsza niż Kolos Rodyjski. Niezachowane to dzieło jest znane $z$ opisu Pauzaniasza, który z jednej strony mówi, że nikt tego posągu nie zmierzył, z drugiej - że wygląda na trzydzieści łokci (ok. 13-15 m) ${ }^{60}$.

Druga z przywołanych rzeźb powstała w drugiej połowie VII w. przed Chr. i stała tuż obok budowli zwanej Ojkosem Naksyjczyków, który prawie na pewno był budowlą kultową. Z proporcji zachowanych destruktów posągu można wydedukować, że miał on wysokość ok. 7-8 m, czyli zbliżoną do wysokości budowli ${ }^{61}$.

Czy, niezależnie od problemu stosunków przestrzennych, miejsce ustawienia wizerunku Heliosa tuż obok świątyni Apollina byłoby właściwe w kontekście ideowym? Vedder usilnie akcentuje, że identyfikacja doryckiej świątyni na rodyjskiej akropoli jako dedykowanej Apollinowi jest oparta na słabych przesłankach ${ }^{62}$. Być może słusznie. Nie można jednak wykluczyć, że już w początkach III wieku przed Chr. na Rodos identyfikacja Heliosa z Apollinem nie była niczym zaskakującym, jako że w niewiele późniejszych czasach stała się zjawiskiem powszechnym ${ }^{63}$. Poza tym jest rzeczą ogólnie znaną

${ }^{60}$ III, 18, 9-16; 19, 1-5. Na temat Tronu Apollina zob. E. Buschor, Vom Amyklaion, „Athenische Mitteilungen“ 1927, 52, s. 1-23, na s. 19 rekonstrukcja rysunkowa obiektu. Według tego autora budowla sięgała tylko do wysokości kolan posągu; zob. też: W. von Massow, Vom Amyklaion. Ausgrabung 1925, ibidem, s. 24-33; idem, Der Thronbau des Bathykles, ibidem, s. 65-85.

${ }^{61}$ Por. M.L. Bernhard, Sztuka grecka archaiczna, Warszawa 1989, s. 104-109, 363370, il. 234-235.

${ }^{62}$ Vedder, Der Koloss..., s. 29 nn. Już niektórzy dziewiętnastowieczni uczeni (Biliotti; C.T. Newton, Travels and Discoveries in the Levant, I, London 1865, s. 169; van Gelder, op. cit., s. 8, 291 n.) zakładali istnienie świątyni Heliosa na rodyjskiej akropoli lub gdzieś w pobliżu, aczkolwiek wówczas, przed rozpoczęciem jakichkolwiek prac archeologicznych, były to tylko spekulacje.

63 Ślady identyfikacji Heliosa z Apollinem można znaleźć już w okresie archaicznym. Najstarsze zachowane przedstawienia Apollina-Heliosa pochodzą z IV w. przed Chr., a w okresie hellenistycznym są już bardzo rozpowszechnione, zob. LIMC V, 1 (N. Yalouris), s. 1033. Dion Chryzostom w Mowie XXXI (do Rodyjczyków), 11, mówi, że dla Rodyjczyków Apollo, Helios i Dionizos to jedno. 
występowanie wizerunków różnych bogów w sanktuariach dedykowanych jakiemuś pojedynczemu bóstwu. Oczywiście z racji wielkości Kolosa jego status powinien być jednak wyjątkowy. Dlatego można przyjąć, że świątynia na akropoli była uważana za poświęconą Heliosowi-Apollinowi, najpóźniej od czasu wystawienia Kolosa. Było to wszak najbardziej efektowne miejsce w mieście. Poza tym zapewne emulacja Rodos z Atenami mogła wpłynąć na jego wybór. Także w Atenach najważniejsze wizerunki ich Opiekunki znajdowały się na Akropolu.

Fakt, że szczątki Kolosa przez wiele wieków pozostawały na miejscu, być może da się wytłumaczyć także tym, że ściągnięcie ich $z$ akropoli wymagało większego nakładu pracy i kosztów, niż gdyby leżały tuż nad morzem.

Wreszcie warto zwrócić uwagę na etymologię słowa "kolos”. Jest ono, zdaniem badacz ${ }^{64}$, pochodzenia małoazjatyckiego i rdzennie oznacza coś wyniosłego. Jako przykład można podać tu nazwy miast: Kolossaj, Kolofon, które rzeczywiście zostały usytuowane na wzniesieniach podobnych do akropoli rodyjskiej.

\section{TECHNIKA WYKONANIA KOLOSA}

Przechodząc teraz do drugiego problemu: jak był wykonany rodyjski kolos, dla niektórych badaczy podstawą do szczegółowych rekonstrukcji techniki był tekst Filona z Bizancjum. Według tegoż autora Chares zbudował bazę $z$ białego marmuru, w której najpierw zamocował nogi posągu aż do kostek ${ }^{65}$. Ślady na bazie po stopach są większe niż przy jakimkolwiek innym posągu ${ }^{66}$. Wyżej nie dało się posągu wznosić inaczej, jak nadbudowując go warstwami, jak budowlę. Posługiwano się przy tym metodą odlewów cząstkowych [?; od-

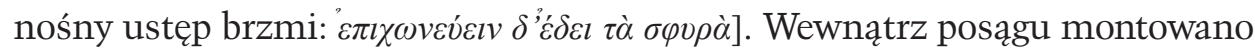
wspomniane już elementy żelazne rusztu i kamienne, te drugie - dla zapewnienia równowagi. Już wykonane partie posągu obsypywano ziemią. $\mathrm{Z}$ tego poziomu odlewano następną wyższą partię rzeźby. Tyle Filon.

Krytykę tego przekazu rozpocznijmy od ostatniej informacji. Już Lüders rozsądnie zauważył, że zamiast usypywać olbrzymie ilości ziemi, prościej by-

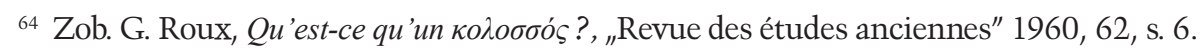

65 Streszczamy tu ten przekaz w zakresie przydatnym dla dyskusji.

${ }^{66}$ Z czego można by wnosić, że autor te ślady widział, a dalej, że wówczas w bazie nie tkwiły już żadne relikty brązowe. Zachowało się do naszych czasów wiele kamiennych baz posągów brązowych: wykonane w nich płytkie zagłębienia służyły do lepszego zamocowania stóp posągu antropomorficznego, które od spodu były podlewane ołowiem. Por. niżej z przekazem Pliniusza. 
łoby ustawiać drewniane rusztowanie, stopniowo podwyższane do aktualnego poziomu roboczego ${ }^{67}$. Mimo to prawie siedemdziesiąt lat później Gabriel podjął próbę przełożenia na konkrety informacji Filona, dając nawet rysunki rekonstrukcyine. Ponieważ jednocześnie zakładał on, że Kolos stał na końcu mola, zdawał sobie sprawę, jak mało było tam miejsca na nasyp ziemny, tym szerszy u podstawy, im wyższy, gdyby usypywano go swobodnie, tj. z zachowaniem kąta stoku naturalnego. Dlatego wymyślił, że od strony zewnętrznej nasyp utrzymywało drewniane, prawie pionowe szalowanie. Przy tym wyraził przypuszczenie, że Charesa na ten pomysł mogła naprowadzić wspomniana już wyżej helepolis. Miała ona rzekomo wysokość zbliżoną do zaplanowanej wysokości Kolosa ${ }^{68}$.

Gabriel nie wziął pod uwagę, jak wielka przy tym rozwiązaniu byłaby siła parcia ziemi na ściankę szalowania, wysoką na ponad 30 metrów. Ażeby ją zrównoważyć, potrzebne byłyby ukośne zastrzały, i to bardzo liczne, jako że podwyższając ściankę, trzeba by ją ponownie podpierać, nie usuwając zastrzałów niższych. Na końcu ich długość wynosiłaby 40-45 metrów. Skąd wziąć drzewa o tak długiej strzale? A gdyby zastrzały były sztukowane, ich nośność byłaby gorsza, a nakład pracy większy. I, przede wszystkim, potrzeba by miejsca na ustawienie zastrzałów niewiele mniej niż przy luźno usypywanym nasypie. Ów „płaszcz” ziemny napierałby także w stronę wnętrza rzeźby, choć w tym przypadku dobrze zaplanowany ruszt metalowy zrównoważyłby siły rozporu.

Jeśliby za dobrą monetę przyjąć te rekonstrukcje zastosowanej technologii, według których kolejne części rzeźby odlewano w piecach umieszczanych na nasypie, przy każdym następnym etapie pracy trzeba by je znosić tylko po to, aby nadsypać ziemi i ponownie je wciągać. Jak? Żurawikami? Były to piece gliniane, które nie wytrzymałyby takich operacji ${ }^{69}$. Kolejnym argumentem przeciw nasypowi jest niemożliwość kontrolowania poprawności syntetycznej artystycznej formy rzeźby, konturu, ale także precyzji połączeń w już zrealizowanych partiach dzieła. Wreszcie sprawa transportu pionowego, materiałów i wykonawców. Przy „płaszczu” ziemnym i tak potrzebne byłyby

${ }^{67}$ Lüders, op. cit., s. 13.

${ }^{68}$ Gabriel, op. cit., s. 338, il. 1-2. Helepolis oczywiście nie mogła być kolista, ze względu na trudności konstrukcyjne.

${ }^{69} \mathrm{~W}$ tej koncepcji wyraźnie widać inspirację przedstawieniami w malarstwie wazowym, ukazującymi nieduży cylindryczny piec, na którym podgrzewa się tygiel z aliażem, zob. kyliks „Malarza Odlewni”, z Berlina, E. Buschor, Griechische Vasenmalerei, München 1925, il. 128; J. Wielowiejski, Górnictwo i metalurgia, w: Kultura materialna starożytnej Grecji. Zarys, red. K. Majewski, I, Wrocław 1975, s. 167 n., il. 16. Zob. też J. Ziomecki, Les representations d'artisans sur les vases antiques, Wrocław 1975. 
drabiny, na końcu prac gigantycznych już rozmiarów i chybotliwe. O wiele bardziej realistyczne jest założenie, że montowany Kolos był otaczany rusztowaniem drewnianym, pomiędzy którego kondygnacjami łatwo było umieścić drabiny lub pomosty komunikacyjne, tak jak to do naszych czasów praktykuje się w budownictwie.

Równie wątpliwą rekonstrukcją technologii wydaje się sugestia odlewania poszczególnych partii in situ, czyli nadlewanie nowych partii brązu nad już wykonanymi częściami rzeźby. W czasach starożytnych odlewów dokonywano w dołach wykopanych w ziemi, w których umieszczano formę przygotowaną do odlewu. Rdzeń posągu był wykonany z gliny z ewentualnymi dodatkami schudzającymi. Na rdzeń nakładano warstwę wosku, w której artysta modelował zewnętrzną artystyczną formę dzieła. Całość wolumenu była oblepiana płaszczem glinianym, w którym pozostawiano otwory wlewowe i kanaliki odpowietrzające ${ }^{70}$. Rdzeń, płaszcz i obsypanie ziemią miało ten dodatkowy walor, że zabezpieczało wlewany aliaż przed gwałtownym i nierównomiernym stygnięciem ${ }^{71}$, w wyniku którego odlew byłby narażony na niejednolitość struktury i raki, ponieważ współczynnik przewodzenia ciepła był podobny dla rdzenia i dla zewnętrznego otoczenia ścianki odlewu. O ile można jeszcze sobie wyobrazić wykonywanie glinianego płaszcza wokół kolejnych partii Kolosa, czyli od strony rusztowania ${ }^{72}$, o tyle od środka rzeźby (gdzie był, według źródeł, ruszt metalowy) dokładanie glinianego rdzenia praktycznie nie wydaje się możliwe. W mniejszych rzeźbach rdzeń po wystygnięciu odlewu był wyskrobywany, np. poprzez otwory u dołu rzeźby, w stopach, lub poprzez szyję ${ }^{73}$. W przypadku Kolosa byłoby to niewykonalne, jako że najniższa jego partia od początku była trwale zamocowana w podłożu. Gdyby natomiast rdzeń pozostawiono, jego ciężar (większy w partii torsu niż w partii nóg) byłby prawdziwym zagrożeniem dla stabilności rzeźby.

W greckiej technice rzeźbiarskiej odlewy cząstkowe w okresie hellenistycznym były już rozpowszechnione. Proces powstawania Kolosa można by więc wyobrażać sobie tak, że w warsztatach usytuowanych na powierzchni terenu wokół powstającej rzeźby przygotowywano odlewy poszczególnych

70 Bardziej szczegółowa charakterystyka technik odlewniczych zob. P.C. Bol, Antike Bronzetechnik. Kunst und Handwerk antiker Erzbildner, München 1985, s. 118 nn.

${ }^{71}$ Ścianka odlewu była bowiem bardzo cienka, od ok. $1 \mathrm{~cm}$ do $1 \mathrm{~mm}$, w zależności od epoki (najgrubsze są odlewy greckie archaiczne).

${ }^{72}$ Choć i w tym przypadku kłopotliwe byłoby transportowanie gliny na coraz wyższy poziom.

${ }^{73} \mathrm{~W}$ odlewach pustych głowa posągu antropomorficznego, także inne części, jak np. ręce, z zasady były odlewane oddzielnie, chyba że odlew był niewielkich rozmiarów (mniejszy niż naturalny). 
partii posągu w wielkościach niezbyt dużych, aby nadmierny ich ciężar nie utrudniał wciągania na rusztowanie. Jednakże w technice odlewów cząstkowych potrzebne było przygotowanie modelu w skali $1: 1$, otaczanego gipsowym płaszczem, który po związaniu był cięty na odpowiednie segmenty, stanowiące negatyw dla danego odlewu cząstkowego. Trudno sobie wyobrazić model ponadtrzydziestometrowej wysokości ${ }^{74}$. Z kolei powiększanie wymiarów z mniejszego modela mogłoby prowadzić do widocznych błędów kompozycyjnych dzieła, tym bardziej że nie wiadomo, czy wykonawcy mogliby posługiwać się cyrklem proporcjonalnym ${ }^{75}$.

Jeśliby założyć tę technologię, należałoby odpowiedzieć, jak odlane płyty były przytwierdzane do wewnętrznego rusztu. W płytach musiałyby więc być pozostawione otworki na nity, i to już raczej w negatywach przed odlaniem. Styki poszczególnych płyt mogłyby być „zespawane”76 aliażem o niższej temperaturze topnienia ( $z$ większym udziałem cyny). Ale wtedy niepotrzebny byłby wewnętrzny ruszt metalowy.

Naszym zdaniem, najprawdopodobniejsza jest hipoteza, że Kolos Rodyjski był wykonany z blach brązowych trybowanych na zimno, przytwierdzanych nitami do metalowego rusztu wewnętrznego ${ }^{77}$. Przy takiej technice łatwiejszy byłby transport pionowy (mniejszy ciężar blach) i możliwość korekt podczas montażu (ze względu na ich większą giętkość).

Byłoby to więc nawiązanie (albo próba odrodzenia) dawnej greckiej techniki sfyrelaton, praktykowanej od czasów geometrycznych i zanikłej w okresie klasycznym. Warto zwrócić uwagę, że w niektórych przytaczanych wyżej źródłach antycznych pojawiają się porównania do pracy cyklopów, do młotów,

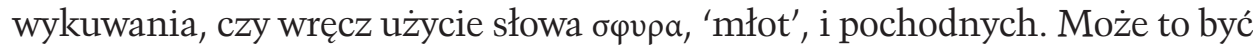
licentia poetica, ale też dowód, że wiedza o rzeczywistej technice wykonania Kolosa w świadomości ludzi starożytności utrzymywała się długo i dotyczy to nie tylko jego konstrukcji wewnętrznej.

Styki pomiędzy poszczególnymi płytami, jak i łebki nitów mogły być maskowane wspomnianymi wyżej „spawami”. Ze względu na niewielką ilość stopu do tego celu potrzebną możliwe wydaje się wykonywanie tych prac na rusztowaniu, z użyciem małych pieców, aczkolwiek już na wysoko-

74 Aczkolwiek Vedder, Der Koloss..., s. 44 n., przyjmuje taką możliwość.

${ }^{75}$ Nie jest to wszakże argument niezbity, jako że już artyści egipscy potrafili, posługując się siatką, kopiować dzieła, powiększając lub pomniejszając je.

76 Tak Lüders, s. 13, który mówi o lutowaniu.

77 Por. H. Maryon, The Colossus of Rhodes, „Journal of Hellenic Studies” 1956, 76, s. 75 nn., 82 n.; D.E.L. Haynes, Philo of Byzantium and the Colossus of Rhodes, „Journal of Hellenic Studies" 1957, 77, s. 311-312. 
ści kilku metrów wiatr znacznie utrudniałby utrzymanie niezbędnej temperatury aliażu (a co dopiero mówić, gdyby na górze odlewano całe partie rzeźby).

Już wiele lat temu badacze zwrócili uwagę na pierwotne znaczenie słowa ко入оббó $\sigma^{78}$. Bynajmniej nie oznaczało ono niczego kolosalnego w dzisiejszym rozumieniu tego słowa. Tak mianowicie określano trójwymiarowe wizerunki odznaczające się bardzo archaicznymi cechami, kojarzące się z pradawnymi okresami historii cywilizacji. Według G. Roux, cechowały się one uproszczonym, kolumnowym korpusem lub postawą ze zwartymi nogami, czy też nawet hermową formą części dolnej ${ }^{79}$. Można przypuszczać, że tego określenia używano do przedstawień antropomorficznych, które dziś nazwalibyśmy hieratycznymi, i to niezależnie od ich skali.

Słowa „kolos” w odniesieniu do niektórych rzeźb egipskich używał już Herodot. Co ciekawe, także w odniesieniu do drewnianych, i to tworzących zespoły po kilkaset sztuk ${ }^{80}$. Nie wydaje się, aby były to rzeźby wielometrowej wysokości, choćby ze względu na permanentne deficyty drewna w Egipcie, choć oczywiście drewno było jedym $z$ tamtejszych rzeźbiarskich tworzyw. Herodot terminem „kolos" określa także rzeźby kamienne stojące na piramidach ${ }^{81}$, na dziedzińcach świątynnych - tu podaje wysokość 12 łokci ${ }^{82}$, a w jednym miejscu pisze także o „wielkich kolosach" ${ }^{83}$. Stąd można wnosić, że w jego mniemaniu kolosy mogą też być małe. Wydaje się, że zarówno w użyciu Herodota, jak i zasadniczo pośród innych Greków słowo to miało bardziej zabarwienie emocjonalne niż stałą zawartość semantyczną. Tak określano rzeczy, które dziś nazywamy „archaicznymi”, a dokładniej mówiąc, „sprawiającymi wrażenie czegoś prastarego". W przypadku Herodota nawet nie potrzeba tego za bardzo udowadniać, jako że z jego dzieła niedwuznacznie wynika fascynacja „odwiecznością” cywilizacji kraju nad Nilem. Ponadto Herodot znał rzeźbę grecką z najlepszego jej klasycznego okresu (przebywał w Atenach w czasach Peryklesa) i w tym kontekście styl tradycyinej rzeźby egipskiej musiał mu wydawać się porównywalny z zabytkami wczesnych etapów rozwoju kultury swojego własnego narodu.

${ }^{78}$ U. von Wilamowitz-Moellendorff, Heilige Gesetze. Eine Urkunde aus Kyrene, „Sitzungsberichte der Preussischen Akademie der Wissenschaften“ 1927, 19, Phil.-Hist. Klasse, s. 167-169; Roux, op. cit., s. 5-40.

79 Roux, op. cit., s. 17, 34.

${ }^{80}$ Herodot, II, 130, 143.

${ }^{81}$ Herodot, II, 149.

82 Herodot, II, 153.

${ }^{83}$ Herodot, II, 176. 
Jest przeto uzasadniona podstawa, aby przypuszczać, że w przypadku Kolosa Rodyjskiego upowszechnienie się tegoż właśnie określenia było determinowane nie tylko zastosowaniem dawnej techniki sfyrelaton, choć zmodyfikowanej, ale także konwencją stylową dzieła. Jak zatem mogło ono wyglądać?

$\mathrm{Na}$ ten temat również są różne poglądy. Niektórzy, biorąc pod uwagę styl epoki, w której dzieło powstało, wyobrażają sobie rodyjskiego Heliosa jako nagiego efeba we wdzięcznym kontrapoście, może z jakimiś atrybutami lub krótką szatą i niezbędną podpórką, np. w formie skałki. Według Hoepfnera, brązowa statuetka znaleziona w Montdidier nad Sommą, obecnie w Luwrze, odzwierciedla wygląd Kolosa Rodyjskiego, nawet z uwzględnieniem korekt optycznych oryginału ${ }^{84}$. Bóg jest w niej przedstawiony jako prawie nagi, jedynie $\mathrm{z}$ krótką szatą $\mathrm{w}$ typie chlamidy, w Lizypowym kontrapoście, z prawą dłonią daleko wysuniętą do przodu w geście pozdrowienia. Tego, że jest to rzeczywiście wizerunek Heliosa, dowodzi corona radiata. Vedder zaś jest zdania, że żadnego znanego antycznego zabytku ikonograficznego nie można wywieść od Kolosa, ale również uważa, że przedstawiał on nagą postaćs5. Zachowana ikonografia Heliosa nie pozwala stwierdzić, jakie było kanoniczne ujęcie przedstawień boga. Prawdopodobnie go nie było. Znane są zarówno przedstawienia nagiej postaci, jak i odzianej ${ }^{86}$.

Rekonstruowanie Kolosa jako postaci nagiej i w kontrapoście, choć atrakcyjne i niepozbawione ikonograficznych analogii, ignoruje wszakże problemy

${ }^{84}$ Hoepfner, Der Koloss..., s. 135, il. 8. Brązowa figurka ma tylko 35 cm wysokości. Zdaniem Hoepfnera jest to $1 / 100$ wysokości oryginału, ibidem, s. 153. Ponadto zwraca on uwagę na dysproporcjonalnie dużą głowę i za długą wyciągniętą rękę, co ma odzwierciedlać korektury optyczne zastosowane w monumentalnym oryginale, oglądanym z żabiej perspektywy. Ponieważ zabytek z Montdidier jest znacznie późniejszy niż początek III w. przed Chr., zatem rodzi się pytanie, jak jego wykonawca mógłby tak precyzyjnie zdjąć wymiary z leżących wówczas na ziemi destruktów Kolosa Rodyjskiego. I w jakim celu? Pomijając praktyczne nieprawdopodobieństwo tej hipotezy, nawet słaby artysta wiedziałby, że korektury wprowadzano po to, aby dzieło w określonych warunkach oglądu wydawało się proporcjonalne. Po co miałby więc oddawać te mankamenty, których twórca oryginału chciał uniknąć? A poza wszystkim, statuetka jest słabą, masową robotą, i stąd są w niej owe nieporadności stylu.

85 Vedder, Der Koloss..., s. 24 n., przyp. 89; autorka wątpi, że figurka z Montdidier jest w całości antyczna, właśnie ze względu na złe jej proporcje.

86 Zob. LIMC V, 1, s. 1007-1034; V, 2, s. 631-657. Wydaje się, że gdy chciano przedstawić boga jako powożącego słoneczną kwadrygą, wówczas przedstawiano go odzianego, bo to było oczywiste z punktu widzenia doświadczenia potocznego: nagi woźnica rychło by się przeziębił. Oczywiście sztuka grecka zna także przedstawienia nagich jeźdźców, bo w sferze idealnej tak trywialne konotacje nie miały znaczenia. Ponadto: możliwość zdynamizowania kompozycji poprzez przedstawienie furkoczącej szaty była atrakcyina. 
techniczne, statyczne i ekspozycyjne tej ogromnej rzeźby. Zupełnie niemożliwe jest, aby jedna stopa była cofnięta i tylko palcami opierała się o podłoże. Przy takim układzie też niemożliwe byłoby wypełnienie wnętrza rzeźby stabilizującymi kamieniami (w co przecież wierzą niektórzy badacze). Poza Kolosa musiała być więc mniej subtelna. Zdając sobie $z$ tego sprawę, Gabriel rekonstruował go jako całkowicie nagą postać, w ujęciu stricte frontalnym, $z$ wyprostowanymi i złączonymi nogami, z wzniesioną pionowo ku niebu prawą ręką, w której trzyma pochodnię ${ }^{87}$. Nogi w tej rekonstrukcji musiały być wyprostowane, gdyż autor sądził, że Chares wypełnił niemal całe wnętrze posągu jakby murowanym z ciosów filarem, w który były wpuszczone metalowe elementy rusztu. Taka konstrukcja nie tylko nie poprawiałaby statyki rzeźby, lecz wręcz przeciwnie - czyniłaby ją ryzykowną ze względu na smukłość filara i jego słabe przewiązanie oraz w związku $z$ tym jego zachowanie przy obciążeniu od parcia wiatru. Maryon widział postać nagą, prawą dłonią osłaniającą czoło, w lewej opuszczonej trzymającą draperię, w której była zamaskowana trzecia podpórka ${ }^{88}$.

Naszym zdaniem, pomysł Charesa mógł przedstawiać się następująco. W dolnej części rzeźby, w bazie i może nieco wyżej, aż do poziomu kostek postaci, znajdowały się owe wspomniane przez Pliniusza kamienie. Byłaby to konstrukcja ze starannie dopasowanych ciosów, połączonych zalewanymi ołowiem klamrami. W ciosach tych były przewiercone otwory, w które wpuszczono dolne końce pionowych elementów rusztu i również je zalano ołowiem. W ten sposób utworzono sztywne zamocowanie dla reszty konstrukcji, którą możemy rozpatrywać według schematu statycznego belki jednym końcem utwierdzonej. Występowałby w niej moment siły od parcia wiatru, znaczny przy długości ramienia ponad 30 metrów. Owa statyczna „belka” w istocie składałaby się z metalowych prętów łączonych nitami, montowanych w taki sposób, że wszystkie one tworzyłyby sieć trójkątów. Czyli innymi słowy, wewnętrzny ruszt byłby kratownicą przestrzenną, być może po raz pierwszy w dziejach cywilizacji zastosowaną ze świadomością zachowania się tego rodzaju konstrukcji. To, że trójkąt jest układem geometrycznie niezmiennym, Grecy musieli wiedzieć od dawna, choćby wskutek doświadczeń w konstruowaniu więźb dachowych i ze szkutnictwa. Do zewnętrznych prętów były nitowane kolejne blachy tworzące powierzchnię rzeźby.

87 Gabriel, op. cit., il. 1 na s. 337.

${ }^{88}$ Maryon, op. cit., s. 72, il. 2-3 (rekonstrukcja inspirowana reliefem z Rodos, il. 1). Kolosa jako postać nagą rekonstruowali też Hoepfner i Vedder, Der Koloss..., s. 25. 
Chares, wprowadzając tak nowatorską konstrukcję89, zapewne miał na uwadze zabezpieczenie Kolosa przed przewróceniem przez wiatr ${ }^{90}$. I to się udało - stał przez kilkadziesiąt lat. Dopiero silne trzęsienie ziemi musiało naruszyć sztywność dolnego zamocowania, wskutek czego wewnętrzny ruszt rozluźnił się i zgiął raczej, niż przełamał, na wysokości kostek W wyniku tego powstała plątanina prętów i blach, zapewne w części tylko rozerwanych. Może także i dzięki temu tak długo zniechęcano się do utylizacji destruktów. Pliniusz pisze, że zaglądano do „czeluści” wewnątrz rzeźby poniżej kostek. Jest to jak najbardziej prawdopodobne, gdy weźmie się pod uwagę, że przełamanie musiało być na wysokości około 2 metrów ponad poziomem podstawy, czyli że zajrzeć było turystom łatwo ${ }^{91}$.

Innym rozwiązaniem korzystnym ze względu na obciążenie wiatrem byłoby zamocowanie rzeźby w podstawie w trzech punktach tworzących wierzchołki trójkąta. Dlatego sugerujemy, że skoro kamiennych elementów konstrukcji nie było powyżej kostek postaci, nogi mogły być w wykroku. Trzeci punkt mogła tworzyć włócznia, berło, gałąź palmowa, tyrs itp. ${ }^{92}$, lub jeszcze bardziej - długa pochodnia, na której wspierał się Helios.

Jakie zatem wrażenie wywierał Kolos Rodyjski? Czy mógł on być w stylu późnoklasycznym lub wczesnohellenistycznym? Ci, którzy chcą widzieć odzwierciedlenia Kolosa w statuetkach nagich postaci w kontrapoście, odpowiedzieliby twierdząco. Wydaje się jednak, że Chares, choć jako uczeń Lizypa doskonale znał ten styl, zdawał sobie również sprawę z olbrzymich trudności zapewnienia bezpiecznej statyki rzeźbie o rozmiarach dotąd niespotykanych. Być może zresztą pierwotny zamysł rzeczywiście był w stylu i w skali Lizypowego Zeusa w Tarencie, czyli Kolos miał być dwukrotnie mniejszy - Chares zamierzał pójść szlakiem już przetartym. Jeśli w anegdocie opowiedzianej przez Sekstusa Empiryka jest jakieś echo rzeczywistych wydarzeń, tak właśnie mogło byćs ${ }^{3}$. Odrzucenie tego projektu pasowałoby do pychy Rodyjczyków, którzy

89 Nowatorska musiała być jednak tylko kratownica przestrzenna. Sama ogólna struktura techniczna miała od dawna swoje źródło inspiracji: posągi chryzelefantynowe. Miały one wewnętrzne ruszty drewniane, czasem $z$ wykorzystaniem dużych kości zwierzęcych, a do tegoż rusztu były przybijane płytki ze złotej blachy i z kości słoniowej. Zob. Bol, op. cit., s. 106.

${ }^{90}$ Niezależnie od tego, czy Kolos stałby na akropoli, czy na molo, wiatr stanowił istotne obciążenie.

91 Stąd też mało prawdopodobna wydaje się wspomniana wyżej informacja Strabona o przełamaniu Kolosa w kolanach.

92 Nie są to typowe atrybuty Heliosa, ale znane z przedstawień, zob. LIMC, V, 1, s. 1028, 1033, kat. 320, 361, 378; V, 2, s. 645-647.

93 Sekstus Empirikus, Przeciwko uczonym, VII, 107 n. 
mogli chcieć posiadać posąg większy od dotychczas najsłynniejszych w świecie greckim i odzwierciedlający ich ekonomiczne możliwości ${ }^{94}$. W tej wymuszonej sytuacji Chares, świadomy trudności technicznych przy tak ogromnym odlewie, być może wpadł na genialny pomysł i zaproponował świadomą archaizację dzieła, i to zarówno pod względem stylu, jak i techniki ${ }^{95}$. Może nawet dzieło o takim wyglądzie miało kojarzyć się z rodyjskimi Telchinami, którzy według mitu pierwsi wykonywali posągi bogów ${ }^{96}$. Nie ulega zresztą wątpliwości, że na Rodos było wiele starych boskich wizerunków, oczywiście mniejszych rozmiarami. Któryś z nich, otoczony powszechną czcią, mógł posłużyć jako wzór i uzasadnienie dla pomysłu Charesa. Chcielibyśmy nawet zaryzykować twierdzenie, że podobnie jak w Atenach Fidiaszowej Atenie Partenos towarzyszył stary ksoanon, główna świętość kultowa, tak też na akropoli rodyjskiej staremu wizerunkowi Heliosa w świątyni ${ }^{97}$ towarzyszył Kolos obok niej.

Czy głowa posągu miała rysy zindywidualizowane, w tym sensie, jak już w sztuce klasycznej utrwaliły się typy wizerunków poszczególnych bóstw? Wydaje się, że nie, choćby dlatego, że przy świadomej archaizacji byłoby to niecelowe. Na potwierdzenie tej hipotezy mamy dość niejasny przekaz Filona, według którego kogo Kolos przedstawia, można było zidentyfikować tylko po cechach jemu właściwych (a może po atrybutach?). Ale jak Filon mógł być wiarygodny, skoro oglądał co najwyżej destrukty? Dwuznaczna jest także opinia Lukiana, który mówi o techne i precyzji wykonania przy tak wielkiej skali Kolosa, przesadnej, jego zdaniem ${ }^{98}$. Podziwia więc raczej to, co wszyscy - cud techniki, choć nie odmawia dziełu pewnej artystycznej klasy. Jak na tak wytrawnego konesera ocena jest jednak powściągliwa. Tu znów to samo pytanie:

${ }^{94}$ Dion Chryzostom, Mowa XXXI (do ludu rodyjskiego, wyd. i tłum. angielskie J.W. Cohoon, H. Lamar Crosby, III, Cambridge, Mass., 1951), 55, mówi: „byliście kiedyś najbogatszymi z Greków i obecnie jesteście bogatsi”. Dion żył w I w. przed Chr. Maryon, op. cit., s. 68, sądzi, że intencją Rodyjczyków było konkurowanie z kolosami egipskimi.

95 Byłby to zatem pionierski znany przykład tendencji historyzującej w sztuce hellenistycznej, lepiej nam znanej od II w. przed Chr. U. von Wilamowitz-Moellendorf, Der verfehlte Koloss, w: Strena Helbigiana, Leipzig 1900, s. 334 n., uważał, że dzieło Charesa nie było stylistycznie wytworne, lecz ułomne.

${ }_{96}$ Diodor, V, 55, 2.

${ }_{97}$ Nie wiadomo, jaki wizerunek kultowy był umieszczony wewnątrz świątyni na akropoli miasta Rodos, zob. V. Machaira, Un Apollon remarquable: analogies thématiques dans la sculpture hellénistique de Rhodes et de Délos, „Revue archéologique” 2014, 2, s. 291. Na niektórych rodyjskich stemplach ceramicznych występuje motyw bardzo archaicznej hermy, zob. Z. Sztetyłło, Les timbres céramiques (1965-1973), Warszawa 1976 („Nea Paphos” I), nr 105-106.

${ }^{98}$ Lukian, Zeus tragik, 11 (tłum. W. Madyda, w: Lukian, Dialogi, I, Wrocław 1957). 
widział Kolosa w destruktach czy zrekonstruowanego (zob. niżej)? Czy może jest to tylko retoryka?

Wielu badaczy chętnie przyięło, że marmurowa głowa Heliosa znaleziona w latach międzywojennych w Rodos jest zmniejszoną kopią głowy Kolosa ${ }^{99}$. Jednak w istocie nie jest to rzeźba pełna, raczej bardzo wysoki relief, pierwotnie od tyłu połączony z jakimś tłem. Ekspresja tego oblicza jest typowa dla sztuki hellenistycznej, pełna patosu. Jest problematyczne, czy podobny efekt można było osiągnąć w technice sfyrelaton. Oczywiście nie da się wykluczyć hipotezy, że Kolos był pod względem technicznym niejednorodny i że na wykonanym w sfyrelaton tułowiu umieszczono odlaną w brązie głowę (miałaby wówczas ok. $5 \mathrm{~m}$ wysokości, co z punktu widzenia techniki odlewniczej jest możliwe, natomiast trudny byłby jej transport na wysokość ok. $30 \mathrm{~m})^{100}$.

Monety rodyjskie, na których niekiedy występuje oblicze Heliosa, nie wydają się odzwierciedlać wyglądu twarzy Kolosa. Pojawiają się bowiem już w końcu V wieku przed Chr. i typ wówczas ukształtowany pozostaje zasadniczo niezmienny w późniejszych czasach ${ }^{101}$. Z tej samej racji nie mogą one oddawać również wyglądu twarzy Heliosa z jego słynnej Kwadrygi autorstwa Lizypa.

Bardzo enigmatyczna jest sprawa ewentualnej restytucji Kolosa w czasach starożytnych ${ }^{102}$. Nie można wykluczyć, że za Hadriana posąg podniesiono albo przynajmniej planowano/usiłowano tego dokonać. Znaczyłoby to, że jeszcze przed czasami Arabów Kolos ponownie runął103.

Podsumowując powyższe rozważania, chcielibyśmy w tym miejscu w zwięzły sposób zwrócić uwagę Czytelnika na te ich aspekty, które wydają się najistotniejsze i które też w jakiś sposób uzasadniają podjęcie tego, wydawałoby się, całkowicie wyeksploatowanego tematu. Co do lokalizacji Kolosa, jest mało prawdopodobne, aby stał on w porcie, w miejscu późniejszego fortu św. Mikołaja, ze względu na trudności z jego godną ekspozycją, kłopotliwym montażem i transportem materiałów oraz ograniczoną dostępnością tego miejsca przez obcych (port wojenny). Ponadto trudno wierzyć, aby destrukty tak wielkiej rzeźby przez kilkaset lat leżały u wejścia do portu; utrudniałyby przecież korzystanie z niego.

99 G.G. Konstantinopoulos, op. cit., il. na s. 61.

100 Por. Bol, op. cit., s. 170.

101 N. Yalouris, T. Visser-Choitz, w: LIMC, V, 1, s. 1022. Być może pod wpływem Kolosa zaczęto dodawać do wizerunków Heliosa koronę promienistą.

102 Zob. wyżej. W źródłach Kolos Rodyjski był niekiedy mylony z rzymskim kolosem Nerona. Zob. też Gelder, op. cit., s. 390.

103 Maryon, op. cit., s. 71, sądzi, że Kolos przełamany pozostawał aż do czasów Arabów, którzy przepiłowali destrukty na wysokości kolan i co było powyżej, wywieźli. Zob. też ibidem, il. 6. Por. wyżej, z informacjami Michała Syryjczyka. 
Wobec wszystkich tych wątpliwości najodpowiedniejszym miejscem wystawienia słynnego dzieła, wydaje się, była akropola miasta. Tu posąg byłby właściwie wyeksponowany zarówno względem miasta, jak i okrętów podpływających z obu stron wyspy.

Kolos, nie ujmując nic jego artystycznemu znaczeniu, był też pomnikiem pychy Rodyjczyków, jako że w ich zamyśle miał przewyższyć rozmiarami kolosy Fidiasza (Zeusa Olimpijskiego, Atenę Partenos).

Opis Kolosa Rodyjskiego pióra Filona z Bizancjum jest w szczegółach niewiarygodny. Jednak próbując go czytać „między wierszami”, można przyjąć, że Chares do wykonania dzieła zastosował zmodyfikowaną technikę sfyrelaton. Stopniowe nadlewanie brązu in situ jest technicznie nieprawdopodobne. W konstrukcji wewnętrznej być może, po raz pierwszy w dziejach, zastosowano kratownicę przestrzenną; to rozwiązanie zabezpieczało Kolosa przed skutkami parcia wiatru (stał przecież lat kilkadziesiąt i jeśli na nadmorskim wzgórzu, to tym bardziej był targany wiatrami), ale nie przed skutkami trzęsienia ziemi.

Archaizowany, naszym zdaniem, musiał też być styl posągu, w szczególności jego poza (a więc świadoma historyzacja, być może zresztą wymuszona trudnościami artystycznego i konstrukcyjnego zadania). Niewykluczone, że głowa odzwierciedlała styl aktualny, choć jest to mniej prawdopodobne: wiemy, że Kolosa podziwiano za ogrom, nie za piękno.

\section{BIBLIOGRAFIA}

Bernhard M.L., Sztuka grecka archaiczna, Warszawa 1989

Bernhard M.L., Sztuka hellenistyczna, Warszawa 1993

Bol P.C., Antike Bronzetechnik. Kunst und Handwerk antiker Erzbildner, München 1985

Brodersen K., Die Sieben Weltwunder. Legendäre Kunst- und Bauwerke der Antike, München 1996

Buschor E., Griechische Vasenmalerei, München 1925

Buschor E., Vom Amyklaion, „Athenische Mitteilungen“ 1927, 52, s. 1-23

Charles P., Bulletin archéologique. Sculpture, statuaire du IVe s. à la fin de l'ère hellénistique. III. Époque hellénistique, „Revue des Études Grecques“ 1943, 56(264$265)$, s. 229

de Choiseul-Gouffier M.G.A.F., Voyage pittoresque de la Grèce, I, Paris 1782

Conrad L.I., The Arabs and the Colossus, „Journal of the Royal Asiatic Society” (seria III) $1996,6,2$, s. $165 \mathrm{nn}$.

Gabriel A., La construction, l'attitude et l'emplacement du colosse de Rhodes, „Bulletin de Correspondance Hellénique" 1932, 56, s. 331-359

van Gelder H., Geschichte der alten Rhodier, Haag 1900 
Gostkowski R., Siedm cudów świata, „Kwartalnik Klasyczny” II, 1928, 4, s. 391-440

Haynes D.E.L., Philo of Byzantium and the Colossus of Rhodes, „Journal of Hellenic Studies" 1957, 77, s. 311-312

Hoepfner W., Der Koloss von Rhodos, „Archäologischer Anzeiger” 2000, 1, s. 129-153

Hoepfner W., Der Koloß von Rhodos und die Bauten des Helios. Neue Forschungen zu einem der Sieben Weltwunder, Mainz 2003

Hoepfner W. et al., Die Epoche der Griechen, w: Geschichte des Wohnens, I, 5000 v.Chr. - 500 n.Chr. Vorgeschichte, Frühgeschichte, Antike, red. W. Hoepfner, Stuttgart 1999, s. 123-608

Kantzia Ch., Zimmer G., Rhodische Kolosse. Eine hellenistische Bronzegusswerkstatt, „Archäologischer Anzeiger" 1989, 4, s. 497-523

Konstantinopoulos G.G., Das Archäologische Museum von Rhodos, Athen [b.r.wyd.]

Laroche D., Jacquemin A., Le char d'or consacré par le peuple rhodien, „Bulletin de Correspondance Hellénique" 1986, 1(110), s. 285-307

Lexicon Iconographicum Mitologiae Classicae (= LIMC), red. gener. L. Kahil, I-IX, Zürich-München-Düsseldorf 1981-1999; Supplementum 2009, Düsseldorf 2009

Lüders K.F., Der Koloss von Rhodos, Hamburg 1865

Machaira V., Un Apollon remarquable. Analogies thématiques dans la sculpture hellénistique de Rhodes et de Délos, „Revue Archéologique” 2014, 2, s. 285-296

Maryon H., The Colossus of Rhodes, „Journal of Hellenic Studies” 1956, 76, s. 68-86

von Massow W., Der Thronbau des Bathykles, „Athenische Mitteilungen” 1927, 52, s. $65-85$

von Massow W., Vom Amyklaion. Ausgrabung 1925, „Athenische Mitteilungen” 1927, 52, s. 24-33

Momigliano A., „Terra Marique“, „Journal of Roman Studies” 1942, 1-2(32), s. 53-64

Morricone L., I sacerdoti di Halios. Frammento di catalogo rinvenuto a Rodi, „Annuario della Reale Scuola Archeologica di Atene” 1949-1951 (wyd. 1952), XXVIIXXIX (N.S. XI-XIII)

Overbeck J., Die antiken Schriftquellen zur Geschichte der bildenden Künste bei den Griechen, Leipzig 1868

Pace B., Scoperte archeologiche a Monte Smith, „Annuario della R. Scuola Archeologica di Atene" 1914, 1, s. 370

Ridgway B.S., Hellenistic Sculpture. I, The Styles of ca. 331-200 B.C., Bedminster/ Bristol 1990

Ross L., Reisen auf den griechischen Inseln des ägäischen Meeres, III, Stuttgart-Tübingen 1845

von Steuben H., Griechische Statuen unter freiem Himmel, „Städel-Jahrbuch“ 1999, N.F. 17 , s. $7-22$

Sztetyłło Z., Nea Paphos I. Les timbres céramiques (1965-1973), Warszawa 1976

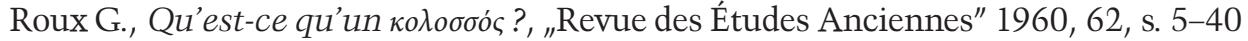

Vedder U., Der Koloss von Rhodos. Archäologie, Herstellung und Rezeptionsgeschichte eines antiken Weltwunders, Mainz 2015

Vedder U., Der Koloss von Rhodos - Neue Perspektiven über das Jahr 2000 hinaus?, w: Proceedings of the XVth International Congress of Classical Archaeology, Am- 
sterdam July 12-17, 1998, red. R.F. Docter, E.M. Moormann, Amsterdam 1999 (Allard Pierson Series 12), s. 335-337

Wielowiejski J., Górnictwo i metalurgia, w: Kultura materialna starożytnej Grecji. Zarys, red. K. Majewski, I, Wrocław 1975, s. 119-224

von Wilamowitz-Moellendorff U., Der verfehlte Koloss, w: Strena Helbigiana, Leipzig 1900, s. 334-335

von Wilamowitz-Moellendorff U., Heilige Gesetze. Eine Urkunde aus Kyrene, "Sitzungsberichte der Preussischen Akademie der Wissenschaften” 1927, 19, Phil.-Hist. Klasse, s. 167-169

Ziomecki J., Les representations d'artisans sur les vases antiques, Wrocław 1975

Tomasz Wujewski

Instytut Historii Sztuki

Uniwersytet im. Adama Mickiewicza w Poznaniu

\section{COLOSSUS OF RHODES:}

WHERE IT STOOD AND HOW IT WAS MADE

\section{Summary}

The author, just as Ursula Vedder, who has expressed the same opinion recently, has been long sure that the place where the Colossus of Rhodes was located was the acropolis of the town of Rhodes. The paper includes also some arguments that have not been presented by the German scholar. At first, some source information concerning the Colossus has been briefly summarized. For instance, the expression in $A P \mathrm{~V}, 171$ (Overbeck 1543), ou gar hyper pelagos monon anthesan alla kai en ga, may be understood as confirming its location in the acropolis: "it stood not only close to the sea, but also on the earth." In fact, there it would have loomed over the land and the sea, and, as big as it was, it could be seen from a distance. The text by Philo of Byzantium is not credible, as it was written quite late. Then the problem has been analyzed critically. As regards the legend of Colossus bestriding the entrance to the harbor, one may add to the already listed counterarguments that for static reasons a piece of sculpture shaped that way would have needed a third footing attached to the sea bottom at the harbor entrance, which would have made the ships' access to the harbor difficult. Besides, such a pose of a god would have seemed a little indecent. A hypothesis that situates the Colossus at the end of a pier in the Mandraki Bay, preferred by many scholars, also has its weak points. Placed there, the construction site would have been too small, particularly that construction took at least twelve years, and it would have been difficult to move building materials along the narrow and long pier which under such circumstances could not be used as part of the harbor. According to Strabo (XIV, 2, 5) the harbor was accessible only to authorized personnel. Was it then a good location for a work of art intended to glorify the people of Rhodes? Even if the Colossus had been accessible there, it would have been visible only in a shortened perspective, in frog's 
eye view. Still, the most important was the problem of proper display of the statue. Placed on the pier, it would have to turn its back either to the town, or to the sea, and in both cases connotations would have been unwelcome. Such details were essential for ancient Greeks. For static and constructional reasons, one must also reject a hypothesis that the Colossus put his palm over the eyes, as if examining the horizon. If it is true that the relics of the statue remained for several hundred years intact, they would have blocked access to the harbor since most probably they would have fallen into the sea. Besides, would the iron elements have resisted corrosion well enough to be recognizable? Placed on the pier, the Colossus would have been invisible to the crews of ships approaching the town from the west and the same would have been true had it been situated at the present location of the palace of the Great Masters of the Knights Hospitaller. The placement of the statue in the sanctuary of Helios at the present corner of Sofouli and Khimaras streets is also improbable, since the area is really small and the Colossus would not have made a prominent component of the town skyline. Hence, the acropolis must have been the most convenient place, just as in other Greek towns, particularly in Athens where it was the site of the city patron's worship. Some scholars argue that the temple in the acropolis was dedicated to Apollo, but when the Colossus was constructed Apollo was commonly identified with Helios who was the most important patron of the island. The statue, with his face turned to the east - the town and the sea - might have stood near that temple (ill. 1-2), towering over it. From the west, the steep rock of the acropolis practically made it impossible to watch the Colossus from the western shore, while from the sea it was visible only as a silhouette, an orientation point for the approaching ships (ill. 3), particularly if it was gilded like the statue of Athena Promachos in Athens. This can actually be the origin of the legend that the Colossus of Rhodes was also a lighthouse. Situated in the acropolis, the statue would have been visible both from the town and the sea on both sides of the island. If the damaged Colossus remained intact for centuries, it was because removing it from the acropolis was much more difficult than removing from the wharf. The noun "colossus" originally meant "something towering" (cf. Colossae and Colophon, towns upon hills). The other part of the paper focuses on the technology of construction. Some scholars were too eager to draw from Philo's description conclusions about the Colossus' structure and the building methods applied. If the statue had stood at the end of the pier, most likely it would not have been hilled up since the area was too small. Due to the pressure of dirt, boarding such an embankment (A. Gabriel's claim) would have required 40-45 meter long struts for which there was no room. Moreover, with each subsequent raising of the embankment the struts would have to be multiplied and made much longer, which would have been both costly and technologically challenging. With each new layer of dirt, founding furnaces would have to be removed (as, according to Gabriel, they were located on the embankment) and then put back. A high embankment would have required the use of gigantic ladders, unstable and dangerous. What is more, it would have made it impossible to control the form of the work in progress. All that would have been irrational, while ancient Greeks do not really deserve such a charge. In the author's opinion, the Colossus was erected within 
a wooden scaffolding. Founding particular elements of the statue on site was rather unlikely. An external dirt coat would not have helped since there was no clay core inside it, which would have made the alloy's cooling speed radically unequal. Partial casting is also unlikely as it would have required a 1:1 model (30-35 meters high). Had the model been smaller, errors in calculating detailed measurements would have been inevitable. The author believes that the Colossus of Rhodes was made of hammered bronze sheets riveted to the inner metal skeleton. Such a technique made vertical transportation easier and allowed the constructors to correct the process of montage by bending the sheets whenever necessary. It cannot be excluded that the heads of the rivets and lines of contact between the sheets were masked with solders that did not require much alloy, although in higher sections of the statue the wind would have cooled it quite rapidly. The noun "colossus" did not originally imply a gigantic size but only a slightly archaic look of the sculpture so that the Colossus of Rhodes might have been somewhat similar to very ancient and artistically primitive stiff statues of Helios. On the other hand, it might have alluded to the mythic Telchins who were the first to make statues of gods. (For static reasons, contrapposto was out of the question in the statues of that size, besides it would have been impossible to fill its interior with stones.) Another aspect of making the Colossus look archaic was the use of a modified technique of sphyrelaton. In the author's opinion, the base of the statue and maybe its higher parts as well, up to the level of ankles, contained carefully sized and braced blocks of stone. They were drilled through to hold the lower ends of the metal internal skeleton made according to the schema of a spatial grid, perhaps used on that occasion for the first time in history. Such a fixture protected the Colossus from the wind pressure so effectively that it remained standing for dozens of years, being vulnerable to earthquakes. The fallen Colossus must have looked like a debris of rods and tin, while the stones from the fixture could be seen in the "abyss" (Plinius), below the level of the ankles, where the structure was actually bent (it must have been bent there rather than at the level of the knees, since looking inside the ruin was easy: the ankles were situated about two meters above the base.) The third footing point might have been camouflaged with some attribute (a spear or a torch). It cannot be excluded that originally Chares had been planning a statue half the final size, similar to the previously known colossal pieces of sculpture, but the pride of the people of Rhodes, emulating Athenians, made them want a Colossus twice as big (Sextus Empiricus, pros mathem., VII, 107 n.). Making the statue look archaic and using an old technology plus some innovations allowed Chares to make their extravagant wish come true. The archaic look might have been achieved thanks to a reference to some old statue of Helios, which perhaps could be found in the neighboring temple. The torso might have been topped with the head, cast separately, although the trouble with placing it so high makes one doubt it.

Keywords:

art of ancient Greece, Hellenistic period, Colossus of Rhodes, problems of location and construction technique 